\title{
Recent Advances in Mouse Models of Sjögren's Syndrome
}

\author{
Yunzhen Gao ${ }^{1}$, Yan Chen ${ }^{1}$, Zhongjian Zhang ${ }^{1}$, Xinhua Yu $^{2 *}$ and Junfeng Zheng ${ }^{1 *}$ \\ ${ }^{1}$ Institute of Psychiatry and Neuroscience, Xinxiang Medical University, Xinxiang, China, ${ }^{2}$ Priority Area Asthma \& Allergy, \\ Research Center Borstel, Airway Research Center North (ARCN), Members of the German Center for Lung Research (DZL), \\ Borstel, Germany
}

Sjögren's syndrome (SS) is a complex rheumatoid disease that mainly affects exocrine glands, resulting in xerostomia (dry mouth) and xerophthalmia (dry eye). SS is characterized by autoantibodies, infiltration into exocrine glands, and ectopic expression of $\mathrm{MHC}$ II molecules on glandular epithelial cells. In contrast to the well-characterized clinical and immunological features, the etiology and pathogenesis of SS remain largely unknown. Animal models are powerful research tools for elucidating the pathogenesis of human diseases. To date, many mouse models of SS, including induced models, in which disease is induced in mice, and genetic models, in which mice spontaneously develop SS-like disease, have been established. These mouse models have provided new insight into the pathogenesis of SS. In this review, we aim to provide a comprehensive overview of recent advances in the field of experimental SS.

Laura Mandik-Nayak,

Lankenau Institute for Medical Research, United States

Efstathia K. Kapsogeorgou, National and Kapodistrian University of Athens, Greece Liangchun Wang,

Sun Yat-sen University, China

*Correspondence:

Xinhua Yu xinhuayu@fz-borstel.de Junfeng Zheng

171013@xxmu.edu.cn

Specialty section:

This article was submitted to Autoimmune and Autoinflammatory

Disorders,

a section of the journal

Frontiers in Immunology

Keywords: Sjögren's syndrome, mouse model, exocrine glands, pathogenesis, autoimmune disease

\section{INTRODUCTION}

Sjögren's syndrome (SS) is a chronic autoimmune disorder characterized by oral and ocular dryness as a result of dysfunction (1). The disease was named after Henrik Sjögren, who was the first person to identify the link among xerostomia, keratoconjunctivitis sicca, and polyarthritis (2). SS is defined as primary SS (pSS) when it presents alone and as secondary SS (2ndSS) when it presents in association with other autoimmune diseases, such as systemic lupus erythematosus (SLE) and rheumatoid arthritis (RA) (3). Similar to many other autoimmune disorders, SS is more common in females than males, with a female:male ratio of $\sim 9: 1$ (4). SS predominantly affects the exocrine glands, leading to dryness in the eyes, mouth, and other organs, including the larynx, trachea, skin, and vagina (5). In addition to the involvement of exocrine glands, extraglandular manifestations, such as inflammatory arthritis, purpura, Raynaud's syndrome, interstitial lung disease, and renal disease, are observed in some patients with SS (6). Immunologically, SS is characterized by the presence of autoantibodies, such as anti-SSA/Ro and anti-SSB/La, focal lymphocytic infiltrates in the exocrine glands, production of inflammatory cytokines, and ectopic expression of MHC II molecules on glandular epithelial cells $(4,7,8)$. In the past two decades, considerable progress has been achieved in our understanding of the pathogenesis of the disease (9). On the one hand, epidemiological, genetic, immunohistochemical, and in vitro studies with samples from SS patients and controls have shed light on the disease pathogenesis of SS (10-12). On the other hand, animal models, particularly mice, provide us with a powerful tool to elucidate the development of human SS (13).

Animal models are invaluable tools for helping us to investigate human autoimmune diseases (14). According to the strategy of disease induction, animal models can be divided into two 
categories: induced models, in which disease is artificially induced in animals (15), and genetic models, in which animals develop disease symptoms spontaneously due to genetic mutations or modifications (16). To date, $\sim 20$ mouse models have been established for SS, including both induced and genetic models. Although these mouse models only partially display the immunological and clinical features of SS, they are highly important for our understanding of the disease. With these mouse models, many essential factors involved in the pathogenesis of SS, including virus infection, autoreactive T cells, B cell hyper-reactivity, autoantibodies, apoptosis of glandular epithelial cells, and dysregulated homeostasis of exocrine glands, have been identified $(13,17)$.

In this review, we aim to provide a comprehensive overview of the recent progress in the mouse models for SS. First, we describe mouse models established for SS (Table 1). Then, we discuss recent findings in the pathogenesis of SS from these mouse models.

\section{MOUSE MODELS OF SS}

\section{Genetic Models}

\section{Nonobese Diabetic (NOD)-Derived Strains}

The nonobese diabetic (NOD) inbred strain was developed as a spontaneous mouse model of type I diabetes (T1D) by Makino et al. at Shionogi Research Laboratories in Aburahi, Japan (42). At $30-40$ weeks of age, $90-100 \%$ of female and 40-60\% of male NOD mice develop T1D (https://www.jax.org/ strain/001976). In addition, NOD mice are characterized by inflammatory cell infiltration in the exocrine glands and impaired secretion of saliva and tears, which resemble the symptoms of SS $(43,44)$. Furthermore, many SS-associated autoantibodies, such as anti-SSA/Ro, anti-SSB/La, anti-120 kD $\alpha$-fodrin, and antimuscarinic type 3 acetylcholine receptors (M3Rs), are present in the serum of NOD mice (44-46). Because NOD mice develop both autoimmune diabetes and SS-like disease, they represent a mouse model of 2 ndSS.

To establish a mouse model of pSS, researchers generated NOD.B10. $H 2^{\mathrm{b}}$, a congenic mouse strain, by replacing the major histocompatibility complex (MHC) I- $A^{g 7}$ molecule of NOD mice with MHC I-A ${ }^{\mathrm{b}}$ from the $\mathrm{B} 10$ strain $(47,48)$. Because $\mathrm{I}-A^{g 7}$ is essential for the development of diabetes and insulitis in NOD mice, NOD.B10. $H 2^{\mathrm{b}}$ mice are protected from autoimmune diabetes but still develop SS-like symptoms, making these mice an ideal model of pSS (49). In addition to NOD.B10. $H 2^{\mathrm{b}}$, another NOD-derived strain used as a mouse model of pSS is C57BL/6.NOD-Aec1Aec2, which has a C57BL/6 background but carries two autoimmune exocrinopathy loci from NOD mice $(46,50)$. C57BL/6.NOD-Aec1Aec2 mice develop many clinical and immunological features resembling pSS, such as impaired production of saliva and tears, increased salivary protein content, aberrant proteolytic enzyme activity, glandular lymphocytic focal infiltrates, and the appearance of autoantibodies $(46,50)$.

As mouse models of SS, NOD-derived strains have been extensively investigated, and many factors, including $\mathrm{T}$ cells, $\mathrm{B}$ cells, various cytokines, and dysregulated homeostasis in exocrine glands, have been shown to contribute to the development of the disease (51-56). Based on the findings from those studies, a three-phase hypothesis of disease manifestation in NOD-derived strains has been proposed. In the first phase ( $0-8$ weeks of age), several aberrant genetic, physiological, and biochemical activities occur prior to the initiation of disease. The second phase (8-16 weeks of age) is characterized by inflammatory cell infiltration in exocrine glands and the production of autoantibodies and proinflammatory cytokines. Finally, in the third phase ( $>16$ weeks of age), the function of the salivary and lacrimal glands (LG) is impaired due to autoimmune-mediated attack $(18,19,57)$. The unique advantage of NOD and NOD-derived models is that disease symptoms develop spontaneously as a polygenic trait, which is similar to the development of human SS. However, due to the high heterogeneity of SS in both symptoms and pathogenesis, NOD and NOD-derived mouse models might resemble the disease in a subgroup of human patients.

\section{NFS/sld Mice}

$\mathrm{NFS} /$ sld mice bear a mutation in an autosomal recessive gene (sublingual gland differentiation arrest, sld), which inhibits the acinar cells of the sublingual gland from differentiating into mucus-secreting cells (21). In 2013, the sld mutation was identified as two intronic CA repeats within the mucin 19 (MUC19) gene; this mutation promotes mRNA decay (20). Notably, when NFS/sld mice were thymectomized 3 days after birth, they spontaneously developed SS-like disease (58) and, thus, represent a mouse model of pSS. The lymphocytic infiltrates in exocrine glands are dominated by $\mathrm{CD} 4^{+} \mathrm{T}$ cells with fewer $\mathrm{CD}^{+} \mathrm{T}$ cells and B cells (58). In 1997, Haneji et al. identified alpha-fodrin ( $\alpha$-fodrin), a $120 \mathrm{kDa}$ salivary gland-specific protein as a disease-relevant autoantigen in this model, suggesting a novel autoantigen in human SS (59).

Several studies have been performed to elucidate the pathogenesis of the pSS-like disease in NFS/sld mice. For example, Ishimaru et al. reported that estrogen deficiency accelerates autoimmune exocrinopathy in these mice, indicating that estrogen plays a protective role in SS (60). In addition, an increase in the number of apoptotic epithelial duct cells in the salivary glands was observed in aged NFS/sld mice, and this increase was further enhanced by estrogen deficiency $(60,61)$. In addition to the increased number of apoptotic epithelial cells, aged salivary glands in the NFS/sld mice showed increased levels of the apoptotic cleavage product of $120 \mathrm{kD} \alpha$-fodrin and autoimmunity to the organ-specific antigen (61), suggesting a role for the apoptosis of epithelial cells in disease pathogenesis. Furthermore, a role of the co-stimulatory molecule CD86 has been suggested by the finding that intraperitoneal administration of anti-CD86 antibody inhibits the development of autoimmune lesions and the production of autoantibodies against $120 \mathrm{kD}$ $\alpha$-fodrin (62).

The NFS/sld model has also been applied to evaluate the role of environmental factors or therapeutics. For example, neonatal NFS/sld mice without thymectomy exposed to an apoptotic dosage of 2,3,7,8-tetrachlorodibenzo-p dioxin (TCDD), an herbicide regarded as a potential environmental trigger for SS, developed autoimmune lesions in the salivary glands and other organs, suggesting a role of TCDD in the disruption 
TABLE 1 | Summary of mouse models of SS.

\begin{tabular}{|c|c|c|c|c|c|c|c|c|c|c|c|c|c|}
\hline & \multirow[t]{2}{*}{ Models } & \multicolumn{4}{|c|}{ Autoantibodies } & \multicolumn{3}{|r|}{ Infiltration } & \multicolumn{2}{|c|}{ Secretion Impairment } & \multirow{2}{*}{$\begin{array}{l}\text { Ectopic } \\
\text { expression of } \\
\text { MHC II }\end{array}$} & \multirow{2}{*}{$\begin{array}{l}\text { Apoptosis of } \\
\text { glandular } \\
\text { epithelial cells }\end{array}$} & \multirow[t]{2}{*}{ References } \\
\hline & & SSA & SSB & M3R & $120 \mathrm{kD} \alpha$-fordin & & & & Salivary & Tears & & & \\
\hline \multirow[t]{14}{*}{ Genetic models } & NOD Jc//ICR & Yes & Yes & Yes & Yes & Yes & Yes & Pancreas & Yes & Yes & ND & Yes & $(18,19)$ \\
\hline & NOD.B10-H2b & Yes & Yes & Yes & ND & Yes & Yes & ND & Yes & Yes & ND & ND & (20) \\
\hline & C57BL/6.NOD-Aec1Aec2 & Yes & Yes & Yes & ND & Yes & Yes & ND & Yes & Yes & ND & Yes & (21) \\
\hline & NFS/sld & ND & ND & ND & Yes & Yes & Yes & ND & Yes & ND & Yes & Yes & $(22-24)$ \\
\hline & IQI/Jic & ND & ND & ND & Yes & Yes & Yes & Pancreas, kidneys, lungs & ND & ND & Yes & ND & (25) \\
\hline & Aly/Aly mice & ND & ND & ND & ND & Yes & Yes & Liver, pancreas, lungs & ND & ND & ND & ND & (26) \\
\hline & Ar KO mice & ND & ND & ND & Yes & Yes & ND & Kidney & ND & ND & ND & Yes & (27) \\
\hline & RbAp48 transgenic mice & Yes & Yes & ND & Yes & Yes & Yes & ND & Yes & Yes & Yes & Yes & (28) \\
\hline & Id3 KO mice & ND & ND & ND & ND & Yes & Yes & ND & Yes & Yes & ND & ND & (29) \\
\hline & PI3K KO mice & Yes & Yes & ND & ND & Yes & ND & Lungs, liver, intestines & ND & ND & ND & ND & (30) \\
\hline & TSP-1 KO Mice & Yes & Yes & ND & ND & ND & Yes & ND & ND & Yes & ND & Yes & (31) \\
\hline & Act1 KO mice & Yes & Yes & ND & ND & Yes & Yes & Kidneys & ND & ND & ND & ND & (32) \\
\hline & BAFF transgenic mice & $\mathrm{N}$ & $\mathrm{N}$ & ND & ND & Yes & Yes & Kidneys & Y & ND & ND & ND & (33) \\
\hline & HTLV-1 tax transgenic mice & ND & ND & ND & ND & Yes & Yes & ND & ND & ND & ND & ND & (34) \\
\hline \multirow[t]{6}{*}{ Induced models } & $\begin{array}{l}\text { Ro60_480-494 induced model } \\
\text { Ro60_274-290 induced model }\end{array}$ & Yes & Yes & ND & ND & Yes & ND & ND & Yes & $\mathrm{N}$ & ND & ND & (35) \\
\hline & Ro60_316-335 induced model & Yes & ND & ND & ND & Yes & Yes & ND & ND & Yes & Yes & No & $(36,37)$ \\
\hline & M3R induced model & ND & ND & Yes & ND & Yes & ND & ND & Yes & ND & ND & Yes & (38) \\
\hline & MCMV induced model & ND & ND & ND & ND & Yes & Yes & ND & Yes & Yes & ND & ND & (39) \\
\hline & CA II induced model & ND & ND & ND & ND & Yes & Yes & Pancreas, kidney & ND & ND & ND & ND & (40) \\
\hline & SG protein induced model & ND & ND & Yes & ND & Yes & $N$ & $\mathrm{~N}$ & Yes & $\mathrm{N}$ & ND & ND & (41) \\
\hline
\end{tabular}

ND, not determined; Yes, presence of the phenotype; No, absence of the phenotype. 
of $\mathrm{T}$ cell tolerance (63). In addition, with NFS/sld mice, both cyclosporine, a potent immunosuppressant (64), and cepharanthine, a biscoclaurine alkaloid, were shown to be effective in the treatment of experimental SS (65).

Because neonatal thymectomy impairs the expansion of regulatory $\mathrm{T}$ cells (66), this model suggests an essential role of regulatory $\mathrm{T}$ cells in the development of the disease. Furthermore, NFS/sld mice represent a powerful tool for investigating the pathogenesis of SS associated with autoantibodies against alphafodrin. However, thymectomy, an indispensable procedure, limits its application.

\section{IQI/Jic Mice}

Similar to NOD mice, IQI/Jic mice were also developed from outbred imprinting control region (ICR) mice in Japan (67). IQI/Jic mice are autoimmune-prone and susceptible to mercuric chloride-induced production of anti-nucleolar antibody (ANA). Moreover, female IQI/Jic mice show focal lymphocyte infiltration and tissue destruction in the salivary glands (SG) and LG. Similar to human SS, to which females are more susceptible than males, more than $80 \%$ of female IQIL/Jic mice spontaneously developed sialadenitis at 6 months of age although male mice showed only mild salivary lesions (22). In addition to exocrine gland infiltration, IQIL/Jic mice show lymphocytic infiltrates in the lungs, pancreas, and kidneys (22), suggesting that the relevant autoantigen(s) might not be tissue-specific. This hypothesis is supported by the identification of kallikrein 13 (Klk13), a protein expressed in multiple tissues as an autoantigen in IQIL/Jic mice (68). In addition to clinical symptoms, immunological features associated with human SS, including antinuclear autoantibodies and aberrantly expressed MHC II molecules on glandular epithelial cells, are present in IQIL/Jic mice (22).

When IQI/Jic mice were thymectomized (Tx) 3 days after birth to eliminate $\mathrm{CD} 4{ }^{+} \mathrm{CD} 25^{+}$regulatory $\mathrm{T}$ (Treg) cells, they developed more severe autoimmune lesions in the lacrimal glands. In addition, the transfer of $\mathrm{CD} 25^{+}$splenic $\mathrm{T}$ cells from normal mice to Tx IQI/Jic mice could inhibit the development of the disease $(23,69)$, suggesting an inhibitory role of Treg cells in this model. In addition, a role of dendritic cells (DCs) has been suggested in these mice because $\mathrm{MHC} \mathrm{II}{ }^{+} \mathrm{CD} 11 \mathrm{c}^{+} \mathrm{B} 7-2\left(\mathrm{CD}^{+} 6^{+}\right)$ DCs were detected in the salivary and lacrimal glands of the mice at 4 weeks of age, and these DCs clustered to form network-like structures at lesion regions (24).

Like NOD mice, IQI/Jic mice develop SS-like disease as a polygenic trait spontaneously resembling the development of human SS. However, the age of onset in this mouse model is at least 9 months, which limits its application. In addition, nonexocrine organs, such as the pancreas, kidneys, and lungs, are also affected in IQI/Jic mice, suggesting that this is a mouse model for 2 ndSS.

\section{Aly/aly Mice}

Aly/aly mice are homozygous for an autosomal recessive alymphoplasia (aly) mutation within the NF-kappa B-inducing kinase (NIK) gene, which leads to the lack of both lymph nodes and Peyer's patches as well as to disorganization of the thymus and spleen $(70,71)$. Although mature $\mathrm{T}$ and $\mathrm{B}$ cells are present, aly/aly mice are deficient in both cellular and humoral immune responses (70). Interestingly, aly/aly mice exhibited chronic inflammatory cell infiltration in multiple organs, including the salivary and lacrimal glands, pancreas, and lungs (72). The inflammatory infiltrates in exocrine glands are predominantly composed of CD4 ${ }^{+} \mathrm{T}$ cells, and the transfer of $\mathrm{T}$ cells from the spleen of aly/aly mice to Rag $2^{-/-}$mice induced inflammation in the exocrine glands and pancreas (72), suggesting an essential role for autoreactive $\mathrm{T}$ cells in this model. However, there are no detectable autoantibodies against nuclear components or salivary gland proteins in the serum of aly/aly mice (72). Notably, aly/aly mice develop systemic disease that can involve multiple organs, and they are also used as animal models for pancreatitis (73), dermatitis (74), and osteoporosis (75).

\section{Ar KO Mice}

SS is highly prevalent in postmenopausal women, implying that estrogen deficiency contributes to the development of this disease. To explore the role of estrogen deficiency in SS, Shim et al. investigated mice deficient in aromatase cytochrome P450, an enzyme catalyzing the formation of estrogens from C19 steroids $(25,76,77)$. Aromatase enzyme knockout ( $A r \mathrm{KO})$ mice show mild splenomegaly and lymphadenopathy as a result of hypercellularity in the bone marrow with the overproduction of mature granulocytes and $\mathrm{B}$ cells (77). Moreover, $\mathrm{Ar} \mathrm{KO}$ mice develop spontaneous autoimmune manifestations, such as proteinuria and severe leukocyte infiltration in the exocrine glands and kidneys, which partially resemble SS $(77,78)$. Additionally, as observed in human SS, Ar KO mice produce proteolytic fragments of $120 \mathrm{kD} \alpha$-fodrin in the salivary glands, and their serum contains autoantibodies against $120 \mathrm{kD} \alpha$-fodrin (77). Taken together, these observations indicate that $A r \mathrm{KO}$ mice are an ideal mouse model for investigating the role of estrogens in the pathogenesis of SS. One limitation of this mouse model could be the age of onset, where $A r \mathrm{KO}$ mice develop SS-like disease at the age of more than 12 months.

\section{RbAp48 Transgenic Mice}

Retinoblastoma-associated protein 48 (RbAp48) is a multifunctional protein that binds to transcription factors and kinases to control cell growth and apoptosis (79). In mice, ovariectomy induces tissue-specific apoptosis in exocrine glands, and $\mathrm{RbAp} 48$ expression is increased in apoptotic glandular epithelial cells (80). Moreover, overexpression of RbAp48 induced apoptosis in epithelial cells with p53 phosphorylation (on Ser9) and $\alpha$-fodrin cleavage, and knockdown of RbAp48 by siRNA inhibited p53-mediated apoptosis (80), suggesting that RbAp48 is functionally involved in the estrogen deficiencymediated exocrine gland-specific apoptosis. To further explore the role of $\mathrm{RbAp} 48$ in the pathogenesis of SS, Ishimaru et al. generated and investigated $R b A p 48$ transgenic mice ( $R b A p 48-t g$ ) overexpressing the gene in a salivary gland-specific manner (80, 81). As expected, the RbAp48-tg mice showed apoptosis in the exocrine glands but not in other organs (80). Moreover, the RbAp48-tg mice developed autoimmune exocrinopathy resembling Sjögren's syndrome, including lymphocytic infiltration in the exocrine glands; the impairment 
of saliva and tear secretion; the ectopic expression of MHC II molecules on glandular epithelial cells; and the production of autoantibodies against SSA/Ro, SSB/La, and $120 \mathrm{kD} \alpha$-fodrin (81). In addition, autoimmune lesions in the exocrine glands can be induced by the transfer of lymph node T cells from $R b A p 48$ Tg mice into Rag2 $2^{-/-}$mice, demonstrating a pathogenic role of autoreactive T cells in this model (81). RbAp48 transgenic mice represent an ideal model for investigating the role of apoptotic glandular epithelial cells in SS. However, this model is fully dependent on the artificial overexpression of $R b A p 48$, a scenario that does not exist in human patients.

\section{Id3 KO Mice}

Id3, a member of the basic-helix-loop-helix (bHLH) transcription factor family, is involved in $\mathrm{T}$ and $\mathrm{B}$ cell selection during lymphocyte development (82, 83). Id3-deficient (Id3 $\mathrm{KO}$ ) mice show reduced $\mathrm{B}$ cell reactivity and a low percentage of single-positive cells in the thymus $(83,84)$. In 2004, Li et al. reported $I d 3 \mathrm{KO}$ mice as a novel mouse model of pSS (85). At the age of 2 months, the exocrine glands of the $I d 3 \mathrm{KO}$ mice show severe lymphocyte infiltration, which is mainly composed of $\mathrm{CD}^{+}{ }^{+} \mathrm{T}$ cells followed by $\mathrm{CD} 8^{+} \mathrm{T}$ cells and $\mathrm{B} 220^{+} \mathrm{B}$ cells (85). Subsequently, the secretion of saliva and tears is significantly decreased in Id $3 \mathrm{KO}$ mice, resulting in dryness in the mouth and eyes. At the age of 1 year, the Id3 KO mice show anti-SSA/Ro and anti-SSB/La antibodies in the serum.

Both $\mathrm{T}$ and $\mathrm{B}$ cells play essential roles in the development of pSS-like disease in Id3 KO mice. On the one hand, the elimination of $\mathrm{T}$ cells in Id3 $\mathrm{KO}$ mice prevented lymphocyte infiltration into the exocrine glands and the impairment of saliva and tear secretion (85), suggesting an indispensable role of $\mathrm{T}$ cells. On the other hand, B cell ablation using an anti-CD20 monoclonal antibody ameliorated the pSS-like disease in Id3 KO mice (26). Therefore, Id $3 \mathrm{KO}$ mice represent a mouse model in which both cellular and humoral autoimmunity contribute to disease pathogenesis, which mimics the situation in human SS. Notably, pSS is not associated with genetic variants in the Id3 gene (86), suggesting potential differences between this model and human disease.

\section{T Cell-Specific PI3K KO Mice}

Phosphoinositide 3-kinase (PI3K), a member of the lipid kinase family involved in diverse cell functions, catalyzes the production of 3-phosphorylated phosphoinositides and serves as a second messenger downstream of many cellular receptors (87). Class IA PI3K, which consists of a catalytic subunit with a molecular weight of $110 \mathrm{kD}$ and a regulatory subunit, plays an important role in the function of lymphocytes (88). To investigate the role of Class IA PI3K in T cells, Oak et al. generated a T cell-specific class IA PI3K-deficient mouse strain (89). Although class IA PI3Kdeficient $\mathrm{T}$ cells show only partial defects in function, the T cellspecific class IA PI3K-deficient mice develop a pSS-like disease. These mice develop corneal opacity and eye lesions resulting from irritation and excessive scratching at an age of 4-12 months (89). In addition, antinuclear, anti-SSA/Ro, and anti-SSB/La antibodies are detectable in the serum of 1 year-old T cell-specific class IA PI3K-deficient mice (89). Histologically, the lacrimal glands of these mice are characterized by destruction of the acinar structure, ductal hypertrophy, and infiltration by lymphocytes, which are composed predominantly of $\mathrm{CD} 4^{+} \mathrm{T}$ cells. In contrast to the lacrimal glands, the salivary glands of $\mathrm{T}$ cell-specific class IA PI3K-deficient mice show levels of inflammatory cell infiltration similar to those in the corresponding controls. Taken together, these findings suggest that $\mathrm{T}$ cell-specific class IA PI3K-deficient mice represent a mouse model for autoimmunitymediated xerophthalmia (89).

\section{TSP-1 KO Mice}

Thrombospondin-1 (TSP-1) is a $450 \mathrm{kD}$ matricellular protein that activates latent transforming growth factor (TGF) $\beta$ in vivo and in vitro $(27,90)$. Consistent with this role, TSP-1-deficient (TSP-1 KO) mice show similar but less severe pathological abnormalities than TGF- $\beta$ 1-null mice (91). By the age of 24 weeks, TSP-1 KO mice develop SS-like disease characterized by increased epithelial cell apoptosis, inflammatory infiltrates in the lacrimal glands, SSA and SSB autoantibodies, and impaired secretion of tears (92). Notably, the development of SS-like disease in TSP-1 KO mice was suppressed by topical application of a TSP-1-derived peptide (KRFK) (93). In vitro findings have demonstrated that the KRFK peptide activates TGF- $\beta$ and, thus, reduces the expression of co-stimulatory molecules on DCs, driving DCs toward a tolerogenic phenotype and ultimately increasing the proportion of Treg cells (93). A limitation of this model is that it only resembles the xerophthalmia of SS patients.

\section{Act1 KO Mice}

Act1 plays an important role in the homeostasis of B cells by negatively regulating CD40- and BAFF-mediated signaling $(28,94)$. As expected, Act1-deficient (Act1 KO) mice show B cell hyper-reactivity and develop systemic autoimmune disease resembling human SS in association with SLE-like nephritis (95). By the age of 6 months, Act $1 \mathrm{KO}$ mice develop oral inflammation with enlarged submaxillary glands and lymph nodes localized proximal to those glands. Furthermore, these mice show severe lymphocyte infiltration in the lacrimal and salivary glands, antiSSA/Ro and anti-SSB/La antibodies in the serum, and impaired secretion of saliva and tears (95). In addition, these mice develop glomerulonephritis (95), making them a useful model for 2ndSS associated with SLE.

With regard to the pathomechanism of SS-like disease in Act1 KO mice, Qian et al. demonstrated that Act1 modulates the survival of autoreactive B cells by regulating BAFF-mediated cell survival and affecting autoantibody production by modulating the CD40-mediated T cell-dependent humoral response (95). In addition, Johnson et al. demonstrated that $\mathrm{T}$ cells are necessary for the development of systemic autoimmune disease in Act1 $\mathrm{KO}$ mice (96).

\section{ERdj5 KO Mice}

The endoplasmic reticulum (ER) serves as the protein-processing factory responsible for proper protein processing, folding, and trafficking. The chaperone protein ERdj5, an ER-resident protein containing DnaJ and thioredoxin domains, is required for the translocation of misfolded proteins during ER-associated protein 
degradation $(29,97)$, the regulation of calcium ion homeostasis in the ER (98), the correct folding of the LDL receptor (99), and the sensitization of neuroblastoma cells to ER stress-induced apoptosis (100). Mice deficient in ERdj5 showed an activated ER stress response in salivary glands (101), suggesting that ERdj5 contributes to ER protein quality control.

It has been shown that ERdj5 is highly expressed in the minor SGs of SS patients, particularly in ductal and acinar epithelium and in the infiltrating mononuclear cells (30). Furthermore, the levels of ERdj5 correlate with the severity of inflammation and anti-SSA/Ro positivity (30), suggesting that ERdj5 might be involved in the development of SS. Notably, ERdj5 KO mice with a129/Sv genetic background spontaneously developed many SS-like features, including inflammation in SGs, increased inflammatory cytokines, apoptosis in SGs, impaired saliva secretion, and production of anti-SSA/Ro and anti-SSB/La autoantibodies (30). Consistent with that in human SS, disease manifestation in ERdj5 $\mathrm{KO}$ mice is associated with sex, where female mice show more prevalent and severe disease than agematched males. The inflammatory infiltrates in SGs of the ERdj5 KO mice mainly include B cells and T cells with an approximate $\mathrm{B} / \mathrm{T}$ ratio of 2:1 that remains unaltered with aging. The ERdj5 KO mice have many immunological, histological, and clinical features of human SSSS, but this model only affects SGs and not LG.

\section{BAFF-tg Mice}

$B$ cell activating factor (BAFF) is a member of the TNF superfamily that acts as a powerful regulator of $B$ cell survival and proliferation (102). Serum levels of BAFF are increased in SLE, SS, and the corresponding animal models, and treatment of lupus-prone mice with the BAFF decoy receptor prevents the onset of disease (103), suggesting an essential role of BAFF in systemic autoimmune diseases. $B A F F$ transgenic C57BL/6 (BAFF-tg) mice overexpressing BAFF develop systemic autoimmune symptoms characterized by $B$ cell hyper-proliferation, high levels of rheumatoid factor and anti-DNA antibody production, SLE-like nephritis, lymphocyte infiltration in the lacrimal glands, sialadenitis, and impaired salivary secretion (104). Unlike the Act1 KO mice, the BAFF-tg mice show no disease pathology in the lacrimal glands and do not produce anti-SSA/Ro and anti-SSB/La antibodies $(31,104)$. Notably, BAFF-tg mice lacking LT-beta and, thus, lacking MZ B cells do develop nephritis but not sialadenitis (105), suggesting that $\mathrm{MZ} B$ cells contribute to the dysfunction of salivary glands in the BAFF- $t g$ mouse model of SS. Similar to Act $1 \mathrm{KO}$ mice, $B A F F$ $\operatorname{tg}$ mice represent a mouse model for SS associated with SLE.

\section{HTLV-1 Tax Transgenic Mice}

Circumstantial evidence suggests that the etiology and pathogenesis of SS are associated with retroviruses, including human T cell lymphotropic virus 1 (HTLV-1) (106). In 1987, Hinrichs et al. generated transgenic mice expressing the HTLV-1 tax gene under the control of viral long terminal repeat (LTR) sequences (107). In addition to developing neurofibromas, the HTLV-1 tax transgenic mice developed SS-like pathology $(32,107)$. Several weeks after birth, the HTLV-1 tax transgenic mice showed ductal epithelial cell proliferation in the exocrine glands without functional impairment and exhibited lymphocyte infiltration. By 8 weeks of age, the HTLV-1 tax transgenic mice showed abnormal ductal cell proliferation as well as severe lymphocytic infiltration into the exocrine glands (32). Thus, the HTLV-1 tax transgenic mice represent a mouse model for investigating the mechanism underlying the association between HTLV-1 and SS.

\section{STAT3 KO and IкB- $\zeta$ KO Mice}

$\mathrm{I} \kappa \mathrm{B}-\zeta$ is a member of the nuclear I $\mathrm{B}$ family of proteins that regulates gene expression via association with NF-кB (108).

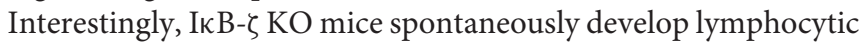
inflammation with mainly $\mathrm{CD} 4^{+} \mathrm{T}$ cells in the lacrimal glands, conjunctiva, and facial skin by the age of 8 weeks regardless of sex (109). With the progression of inflammation, high titers of anti-SSA and anti-SSB autoantibodies as well as impaired ear

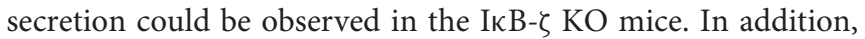
aged IкB- $\zeta$ KO mice often exhibited interstitial pneumonia, a frequent complication of SS (109). Notably, in the IкB- $\zeta$ KO mice, epithelial cell apoptosis preceded lymphocyte infiltration, supporting an etiological role of epithelial cell apoptosis in human SS.

Signal transducers and activators of transcription 3 (STAT3) are regulators of $\mathrm{I} \kappa \mathrm{B}-\zeta$ expression (110) and are required for the expression of $\mathrm{I} \kappa \mathrm{B}-\zeta$ in the epithelial cells of lacrimal glands (109). Interestingly, both epithelial cell-specific IкB- $\zeta$ KO mice and epithelial cell-specific STAT3 KO mice show SS-like phenotypes, such as lymphocyte-infiltrating periocular dermatitis, dacryoadenitis, conjunctivitis, autoantibodies against SSA and SSB, and impaired tear secretion, suggesting a role of dysregulated homeostasis of epithelial cells in the pathogenesis of the disease (109). However, a limitation of STAT3 KO and IкB- $\zeta$ $\mathrm{KO}$ mice is that only lacrimal glands are affected.

\section{Induced Mouse Models \\ Salivary Gland Protein-Induced Mouse Model}

Similar to induced models of many other autoimmune diseases (14), the first induced model of SS was established by immunizing animals with tissue/cell extracts. In 1974, White et al. reported an experimental rat model of sialadenitis induced by immunization with allogeneic submandibular gland homogenate emulsified in Freund's complete adjuvant (FCA) (111). By immunizing mice with syngeneic submandibular gland homogenate, Yasunori et al. induced the first experimental model of autoallergic sialadenitis resembling human SS (112). By 4 weeks after immunization, the $\mathrm{SL} / \mathrm{Ni}$ mice showed "marked lymphoid cell infiltration in the submandibular glands with high incidence and proliferation of duct epithelial" (112). In addition to SL/Ni mice, C57BL/6 mice are susceptible to the development of salivary gland proteininduced SS-like disease $(113,114)$. After immunization, C57BL/6 mice show enhanced apoptosis and increased expression of M3R in the salivary glands. Furthermore, immunized C57BL/6 mice produce autoantibodies against $\mathrm{M} 3 \mathrm{R}$ and show inflammatory infiltration in the salivary glands and reduced saliva secretion (114, 115). In addition, an enhanced Th17 cell response has been observed in the cervical lymph nodes and salivary glands 
of C57BL/6 mice during the development of disease (114). In contrast, IL-17-deficient mice are completely resistant to the development of disease (114), suggesting an indispensable role of IL-17 in this model. Because salivary gland proteins represent a complex mixture of antigens, a limitation of this model is the unknown pathogenic autoantigen(s).

\section{Carbonic Anhydrase II-Induced Mouse Model}

Carbonic anhydrase II (CAII) is a human $\alpha$ carbonic anhydrase that catalyzes the reversible hydration of carbon dioxide (116). Although autoantibodies against CAII are a hallmark of autoimmune pancreatitis (117), they are also associated with other autoimmune diseases, including SS and SLE (118, 119). Interestingly, PL/J $\left(H-2^{u}\right)$ mice immunized with CAII showed severe lymphocyte infiltration around the intercalated and intralobular ducts in the salivary and lacrimal glands (120). In addition, similar lymphocyte infiltration was observed in the kidneys and pancreas of a small number of immunized mice (120). Consistent with the observation that human SS is associated with HLA $(33,121)$, the development of the CAII-induced mouse model is associated with the $H-2^{s}$ and $H-2^{u}$ haplotypes. Although PL/J $\left(H-2^{u}\right)$ mice immunized with CAII represent a novel induced mouse model for SS, its relevance to human disease might be low because CAII is unlikely to be a major target antigen in patients (122).

\section{M3R Immunization}

M3R is one of five members of the family of muscarinic receptors that mediate many physiological responses, such as smooth muscle contraction, heart rate, and glandular secretion (123). Because M3R is involved in the regulation of the secretory function of exocrine glands, it is conceivable that autoantibodies against M3R with an antagonistic effect can impair the secretion of saliva and tears $(34,124,125)$, making M3R a putative autoantigen in SS. To determine the pathogenicity of autoimmunity against M3R in vivo, Iizuka et al. immunized M3R-deficient $\left(M 3 R^{-/-}\right)$mice with a six-valent (N-terminus 1, N-terminus 2, N-terminus 3, 1st extracellular loop, 2nd extracellular loop, and 3rd extracellular loop) mixture of murine M3R peptides and then transferred splenocytes from the immunized mice into $R A G 1^{-/-}$mice (126). As expected, the recipient $R A G 1^{-/-}$mice produced high levels of anti-M3R antibodies, suggesting strong immune responses against M3R. Furthermore, the recipient mice showed apoptotic glandular epithelial cells and severe lymphocyte infiltration with predominantly $\mathrm{CD}^{+} \mathrm{T}$ cells in the salivary glands as well as impaired secretion of saliva, resembling human SS. Therefore, this M3R-induced mouse model supports the hypothesis that M3R is a putative autoantigen in human SS. Notably, the transfer of $\mathrm{CD}^{+} \mathrm{T}$ cells isolated from immunized $M 3 R^{-1-}$ mice into Rag1 ${ }^{-/-}$mice was sufficient to induce SS-like disease, suggesting that autoreactive $\mathrm{T}$ cells against M3R are the key player in the pathogenesis of this model (126). This hypothesis is further supported by another study in which Tahara et al. showed that administration of $\mathrm{A} 213$, a potent and selective $R O R \gamma t$ antagonist that inhibits the differentiation of $\mathrm{CD}^{+} \mathrm{T}$ cells into Th17 cells, could prevent M3R-induced SS-like disease (127). Taken together, these findings indicate that, in this mouse model, $\mathrm{T}$ cell responsesparticularly Th17 responses-to M3R are pathogenic, but autoantibodies against M3R peptides do not play an essential role in the development of disease. The non-pathogenic role of autoantibodies against the M3R peptide was also shown in another study, in which Chen et al. immunized BALB/c mice with a peptide of the 2nd extracellular loop of murine M3R that contains the binding site of the ligand. Although the immunized mice generated autoantibodies against the peptide of the 2nd extracellular loop of murine M3R, they showed no histological or pathological abnormalities in the exocrine glands (127).

\section{Ro60 Peptide-Induced Mouse Model}

Anti-SSA/Ro autoantibodies, a diagnostic biomarker for SS, are present in the serum of $\sim 75 \%$ of patients with SS (128). In 2005, Scofield et al. immunized BALB/c mice with Ro60 peptides, which contain epitopes recognized by SSA autoantibodies from SS patients (41). After repetitive immunization with the Ro60_480-494 or Ro60_274-290 peptide emulsified in CFA, mice developed both anti-SSA/Ro and anti-SSB/La antibodies, suggesting intermolecular epitope spreading. By 263 days after the first immunization, the mice showed lymphocytic infiltrates composed of both $\mathrm{T}$ cells and $\mathrm{B}$ cells in the salivary glands and a significantly decreased salivary flow rate (41). Unlike the BALB/c strain, the DBA-2, PL/J, SJL/J, and C57BL/6 strains are resistant to Ro60_274-290 peptide-induced SS-like disease; the SJL/J strain showed no immune responses to the peptide, and the other three strains reacted to the peptide but showed no disease symptoms (129).

In 2017, Zheng et al. reported another mouse model of SS induced by immunizing mice with the Ro60 peptide (130) in which mice are immunized with the Ro60_316-335 peptide containing a dominant $\mathrm{T}$ cell epitope (131). A single immunization with the Ro60_316-335 peptide emulsified with TiterMax as an adjuvant induced the production of autoantibodies recognizing multiple lacrimal proteins, suggesting intermolecular epitope spreading. By 12 weeks after immunization, $\mathrm{C} 3 \mathrm{H} / \mathrm{He}$ mice showed lymphocyte infiltration into the lacrimal glands and impaired tear secretion, but no histological or pathological abnormalities were observed in the salivary gland. Among the four mouse strains, the $\mathrm{C} 3 \mathrm{H} / \mathrm{He}$ and $\mathrm{BALB} / \mathrm{c}$ strains were susceptible but the DBA/1J and C57BL/6J strains were resistant to the Ro60_316-335 peptide-induced SS-like disease (131). Notably, ectopic expression of MHC II molecules on the glandular epithelial surface, a feature of human SS, has been observed in this model as a pre-symptomatic event, and the ectopic expression of MHC II molecules is mediated by the adjuvant (132). In addition, depletion of B cells with an anti-CD20 monoclonal antibody could prevent mice from developing SS-like disease, suggesting an essential role of B cells in disease pathogenesis (130). Given that anti-Ro60 autoantibodies are not pathogenic, the pathogenic mechanism of the Ro60 peptide-induced models remains unclear. 


\section{MCMV-Induced Mouse Model}

Human CMV virus replicates mainly within the ductal epithelium of the salivary glands although murine CMV (MCMV) virus replicates primarily within the acinar epithelial cells of the submandibular glands $(40,133)$. To investigate the relationship between CMV and human SS, Fleck et al. induced MCMV infection by intra-peritoneal injection into four mouse strains: C57BL/6, Fas-deficient B6-lpr/lpr, TNFRI-deficient B6$\operatorname{tnfr} 1^{0 / 0}$, and B6-tnfr $1^{0 / 0}-\operatorname{lpr} / \mathrm{lpr}$ (134). Mice of all of these strains developed acute sialadenitis at 28 days after infection, but only the B6-lpr/lpr mice showed SS-like symptoms, such as severe salivary gland inflammation and anti-SSA/Ro and antiSSB/La antibody production at 100 days after infection (135). Because the B6-lpr/lpr strain has an autoimmune background, this finding suggests that the MCMV-induced SS-like disease is a result of the interaction between viral infection and preexisting autoimmunity. This hypothesis is further supported by another study in which SS-like disease was induced by MCMV infection in another autoimmune-prone strain, NZM2328 (136). This virus-induced SS-like disease in mice represents a mouse model for $2 \mathrm{ndSSc}$, and it is useful to explore the role of viral infection in the etiology and pathogenesis of SS. However, this model can only be induced in autoimmune-prone strains, which limits its utility.

\section{Adenovirus 5 (AdV5)-Induced Mouse Model}

Salivary glands in $30-40 \%$ of patients with SS develop ectopic lymphoid structures (ELS) that contain T and B lymphocytes, follicular dendritic cells, and auto-reactive plasma cells (137, 138). To explore the key molecular and cellular events regulating the formation of ELS, Bombardieri et al. induced replicationdeficient adenovirus-5 (Adv5) infection in the submandibular glands of C57BL/ 6 mice by retrograde excretory duct cannulation (139). Adv5 delivery in the submandibular glands (SMGs) could induce the formation of ELS and many other SS-like features in a dose-dependent manner. By week 3 post-cannulation, the mice strongly showed several cardinal features of SS, including infiltration of $\mathrm{T}$ and $\mathrm{B}$ cells, formation of ELS, development of anti-nuclear antibody (up to $75 \%$ of mice), and reduction in salivary flow (139). Immunofluorescence staining showed that Adv5-induced ELS in C57BL/6 cells is characterized by T/B cell segregation, differentiation of high endothelial venules, development of follicular dendritic cell networks and formation of GL7+ germinal centers. Further studies suggested that Adv5induced CXCL13 and CCL19 are two important chemokines for the formation of ELS $(38,140)$. In addition, Adv5 infection could induce the formation of a network composition by a population of podoplanin-positive $(\mathrm{pdpn}+)$ stromal cells that preceded lymphocyte infiltration in the tissue mediated by paracrine and autocrine signals, which were mainly regulated by IL13 (141). Once lymphocytes were recruited, the production of the tissue local cytokines IL22 and lymphotoxin expanded and stabilized the initial fibroblast network. Depleting the immunofibroblasts or inhibiting the pdpn+ network regulatory events resulted in abrogation of local pathology (141). The Adv5 deliveryinduced model provides a unique tool to explore the mechanisms underlying ELS formation and the pathology of ELS-associated SS. For example, using this model, Nayar et al. showed that the
$\mathrm{Pi} 3 \mathrm{~K} \delta$ pathway within the glands contributes to ELS formation and disease manifestation (35).

\section{WHAT HAVE WE LEARNED FROM THESE MOUSE MODELS OF SS}

The mouse models of SS have extensively elucidated the pathogenesis of the human disease. According to their roles in the mouse models of SS, factors that contribute to the development of disease can be divided into two major categories: alterations in the immune system and dysregulation of exocrine gland homeostasis (Figure 1).

\section{Alterations in the Immune System Role of DCs}

DCs, a key type of antigen-presenting cells (APCs), are essential for the initiation of adaptive immune responses, including the generation of autoreactive $\mathrm{T}$ cells and regulatory $\mathrm{T}$ cells (Tregs). The essential role of DCs in the development of SS-like disease is supported by several mouse models. For example, in mouse models induced by immunization with antigens, such as salivary gland proteins (112), the CAII protein (120), or the M3R (126) and Ro60 peptides $(126,130)$, it is clear that DCs are involved in processing and presenting antigens to T cells. In genetic models, a role of DCs is suggested in TSP-1 KO mice, where TSP-1 deficiency decreases the activation of TGF- $\beta$, thus enhancing the expression of co-stimulatory molecules on DCs, leading to autoimmunity and autoimmune diseases $(92,93)$.

\section{Role of T Cells}

One of the key features of human SS is the abnormal activation and expansion of autoreactive $\mathrm{T}$ cells $(36,114,142)$, suggesting an important role of $\mathrm{T}$ cells in disease pathogenesis. This idea is strongly supported by findings from animal models. For example, $\mathrm{T}$ cells are the predominant cell type in the inflammatory cell infiltrates in exocrine glands in all mouse models, consistent with observations in human SS. Furthermore, mouse models of SS provide direct evidence for an essential role of $\mathrm{T}$ cells in disease pathogenesis. First, the transfer of T cells from diseased mice in multiple models induced SS-like disease in recipient immunodeficient mice $(37,71,81,126)$, suggesting that $\mathrm{T}$ cells are sufficient to induce disease. Second, deficiencies in $\mathrm{T}$ cells or T cell-associated cytokines, e.g., IL-17, prevented mice from developing SS-like disease $(85,96,114)$, demonstrating that $\mathrm{T}$ cells are indispensable for disease development. Third, mice with a T cell-specific PI3K deficiency spontaneously developed SS-like disease, showing that abnormalities in $\mathrm{T}$ cells mediate disease manifestation. Finally, several mouse models have shown that autoreactive T cells against M3R (126) and $120 \mathrm{kD} \alpha$-fodrin (81) are potentially pathogenic.

In addition to autoreactive $\mathrm{T}$ cells, Tregs have been shown to contribute to disease development in mouse models, which is best exemplified by the NFS/sld, IQI/Jic, and Ar KO mice (23, 37, $58,69)$. In these genetic models, mice that were thymectomized (Tx) 3 days after birth to eliminate Tregs developed severe disease symptoms, suggesting a protective role of Tregs. 


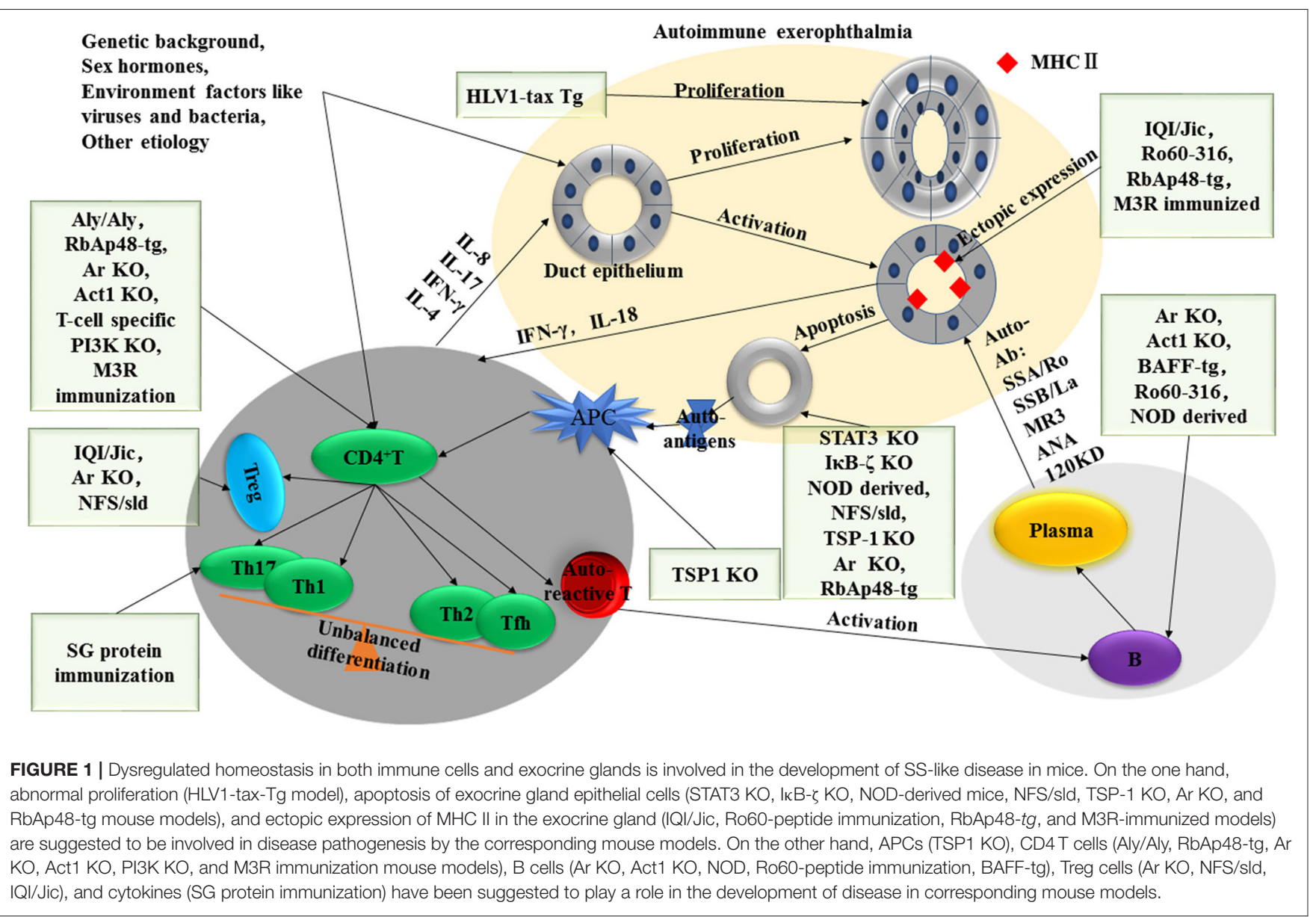

\section{Role of B Cells and Autoantibodies}

Findings from animal models also demonstrated an essential role of B cells in the development of SS-like disease. On the one hand, genetic modifications directly affect $\mathrm{B}$ cell function; for example, mice with Act1 deficiency (95) and BAFF overexpression (103) spontaneously develop SS-like symptoms, demonstrating that B cell dysregulation could lead to SS-like disease. On the other hand, B cell deficiency mediated either by genetic modification (54) or by anti-CD20 antibodies $(26,130)$ inhibits disease development in multiple models, suggesting an indispensable role of B cells. Because B cells are involved in both antibody production and antigen presentation, an essential role of $\mathrm{B}$ cells in mouse models of SS indicates but does not necessarily confirm that autoantibodies are pathogenic. In 1998, Robinson et al. reported that the transfer of IgG isolated from NOD mice but not normal mouse IgG could decrease saliva production (54), demonstrating for the first time the pathogenic role of autoantibodies in animal models. Notably, B cell-deficient NOD mice, NOD.Ig $\mu^{\text {null }}$ mice, develop exocrine gland lesions similar to those observed in NOD mice but show normal secretory function (54). These findings suggest that $B$ cells are not required for the formation of inflammatory cell infiltrates, but play an indispensable role in the impairment of secretory function via autoantibody production.

\section{Role of Dysfunctional Homeostasis of Glandular Epithelial Cells}

As a consequence of disease manifestation, exocrine gland dysfunction is a key feature of SS with more than $90 \%$ of patients exhibiting impaired secretory function of the salivary and/or lacrimal glands (143). Interestingly, evidence from mouse models of SS suggests that dysregulation of exocrine gland homeostasis also contributes to the development of the disease.

\section{Glandular Epithelial Cell Apoptosis}

In human SS, both the salivary and lacrimal glands exhibit characteristic apoptosis of glandular epithelial cells (144). This glandular epithelial cell apoptosis has been observed in many mouse models of SS, for example, in NOD-derived strains (145147), Ar KO mice (37, 77), RbAp48-tg mice (80), NFS/sld mice $(60,61)$, STAT3 KO mice (109), and TSP-1 KO mice (92). Notably, in these mouse models, epithelial cell apoptosis is an event preceding autoimmune responses, suggesting that it might be the causal factor of autoimmunity. This hypothesis is well-supported by findings in RbAp48-tg mice as mice overexpressing the gene in a salivary gland-specific manner showed tissue-specific epithelial cell apoptosis in the exocrine glands (80). Subsequent to epithelial apoptosis, RbAp48-tg mice show autoreactive $\mathrm{T}$ cells and autoantibodies, which lead to 
further histological lesions and exocrine gland dysfunction (80). Therefore, the findings in RbAp48-tg mice clearly demonstrate that the apoptosis of glandular epithelial cells can trigger autoimmune responses in SS.

The mechanism underlying epithelial cell apoptosis-triggered autoimmunity has also been partially explored in mouse models of SS. In multiple mouse models characterized by epithelial cell apoptosis, autoantibodies against the proteolytic fragments of $120 \mathrm{kD} \alpha$-fodrin are observed $(37,60,61,77,80)$, suggesting that autoimmunity against $\alpha$-fodrin is mediated by epithelial apoptosis. Moreover, the increase in apoptotic epithelial cells is associated with increased proteolysis of $120 \mathrm{kD}$ alpha-fodrin in the salivary glands of $\mathrm{Ar} \mathrm{KO}$ mice and NFS/sld mice (61, 77). In addition, increased $\alpha$-fodrin proteolysis led to enhanced $\mathrm{T}$ cell responses against $\alpha$-fodrin, and passive transfer of $\alpha$ fodrin-reactive $\mathrm{T}$ cells could induce inflammatory lesions in the exocrine glands of recipient mice (37). Therefore, these findings suggest that the axis of glandular epithelial apoptosis/ $\alpha$-fodrin proteolysis/autoimmunity against $\alpha$-fodrin plays an essential role in the development of SS-like disease.

\section{Ectopic Expression of MHC II Molecules}

Ectopic expression of MHC II molecules on glandular epithelial cells is another histological characteristic of SS (8). In 1997, Saegusa et al. reported that IQI/Jic mice show expression of MHC II antigen on ductal epithelial cells in the foci (22). Abnormal expression of MHC II molecules on glandular epithelial cells was also observed in RbAp48-tg mice (81). Because both IQI/Jic and $R b A p 48$ - $\operatorname{tg}$ mice are genetic models of SS, these findings suggest that this ectopic expression is mediated by genetic factors. Regarding the mechanism underlying ectopic expression, IFN- $\gamma$ produced by salivary gland epithelial cells in RbAp48-tg mice (81) plays an essential role in this process because it can induce high expression of interferon regulatory factor 1 (IRF-1) and class II major histocompatibility complex transactivator (CIITA), which are primary regulators of MHC II molecules $(39,148,149)$.

In addition to that in genetic mouse models, ectopic expression of MHC II molecules on glandular epithelial cells has been observed in two induced mouse models: the M3R immunization-induced model (126) and the Ro60_316-335 peptide-induced mouse model (132). Interestingly, in the Ro60_316-335 peptide-induced model, ectopic expression of MHC II molecules is caused by the adjuvant and is an early pre-symptomatic event during the development of disease (132), suggesting that (i) ectopic expression of MHC II molecules can also be caused by environmental factors and (ii) ectopic expression of MHC II molecules might be involved in the development of disease.

Due to the essential role of MHC II molecules in antigen presentation, glandular epithelial cells ectopically expressing MHC II molecules might act as APCs and, thus, contribute to the development of SS-like disease. This idea is supported by a previous finding that salivary gland epithelial cells (SGECs) obtained from patients with SS express both MHC II molecules and co-stimulatory cytokines and can mediate the initiation, development, and maintenance of the inflammatory response as nonprofessional APCs in vitro (81).

\section{Abnormal Proliferation of Glandular Epithelial Cells}

In addition to apoptosis and ectopic expression of MHC II molecules, abnormal proliferation of glandular epithelial cells might also promote autoimmunity (2). In the HTLV-1 tax Tg model, young mice showed ductal epithelial cell proliferation in the exocrine glands. As the mice aged, they showed a distorted structure and severe lymphocytic infiltration into the exocrine glands (32). These data indicate that the proliferation and functional perturbation of ductal epithelial cells in the exocrine glands might be the primary event mediating the subsequent autoimmunity and lymphocyte infiltration in SS. The mechanism underlying this phenomenon needs to be further elucidated.

\section{CONCLUSION}

The short life span, high fertility, genetic similarity to humans, and the fact that the mouse genome can be readily manipulated make the mouse the most common model organism for human diseases, including autoimmune disorders $(150,151)$.

The existing mouse models have two major limitations. On the one hand, patients with SS are characterized by a broad clinical spectrum, including glandular and extraglandular manifestations as well as the development of B cell malignancy. However, no single mouse model has captured all immunological and clinical aspects of human SS. On the other hand, patients with SS can be categorized as those with mild disease, e.g., patients with only dry eye and/or dry mouth, or those with severe systemic disease, e.g., patients with severe interstitial lung disease. However, most mouse models for SS only develop a mild disease, and there is a lack of mouse models that show symptoms similar to pSS with systemic diseases with the exception of some mouse models for 2ndSS, such as NOD mice and BAFF$\operatorname{tg}$ mice, which develop multiple autoimmune disorders. The discrepancies between human disease and mouse models may be due to several reasons. First, species differences between mice and humans in the immune systems and affected tissues might lead to different disease manifestations (151). Second, all mice used for modeling human SS are inbred strains, which cannot mimic the genetic heterogeneity of human patients. Finally, human SS is a complex disease resulting from the interaction of multiple genetic and environmental factors, and most mouse models are either caused by a single genetic variation or induced by immunization with an antigen or viral infection. Thus, an ideal mouse model that mimics the full profile of human SS is still missing. For better modeling of human SS, novel and more representative disease models need to be developed in the future.

Nevertheless, the existing mouse models for SS are important for the investigation of the significance of certain pathways and etiopathogenic factors in human SS. For example, mouse models have already uncovered some potential etiologic factors for SS, including viral infection, estrogen deficiency, and apoptosis of exocrine glandular epithelial cells. Moreover, mouse models have demonstrated that pathogenic autoimmunity in SS can result from dysregulated $\mathrm{T}$ cell development or activation, uncontrolled activation of $\mathrm{B}$ cells and abnormal 
function of APCs. In addition, induced mouse models suggest that autoimmunity to salivary gland proteins, M3R, Ro60, and CAII might play a role in the development of SS. With regard to pathogenesis, Th17 cells; B cells; and some inflammatory cytokines, such as IL-8, IL-17, and IFN- $\gamma$, have been suggested to play an important role in disease manifestations (152).

In conclusion, SS is a highly complex and heterogeneous autoimmune disease with multifactorial etiology. Often, human SS coexists with other autoimmune diseases, such as RA or SLE, which are additional obstacles to exploring the pathogenesis of the disease. Mouse models are powerful tools for exploring the etiology and pathogenesis of human SS. In the past two decades, significant progress has been achieved in the field of mouse models of SS, which has helped elucidate the nature of the disease. Research has shown that both abnormalities in the immune system and dysregulated homeostasis in the exocrine glands are involved in the development of SS. Additional and

\section{REFERENCES}

1. Tucci M, Quatraro C, Silvestris F. Sjogren's syndrome: an autoimmune disorder with otolaryngological involvement. Acta Otorhinolaryngol Ital. (2005) 25:139-44.

2. Jonsson R, Moen K, Vestrheim D, Szodoray P. Current issues in Sjogren's syndrome. Oral Dis. (2002) 8:130-40. doi: 10.1034/j.1601-0825.2002.02846.x

3. Shiboski SC, Shiboski CH, Criswell L, Baer A, Challacombe S, Lanfranchi H, et al. American college of rheumatology classification criteria for Sjogren's syndrome: a data-driven, expert consensus approach in the Sjogren's International Collaborative Clinical Alliance cohort. Arthritis Care Res. (2012) 64:475-87. doi: 10.1002/acr.21591

4. Mavragani CP, Moutsopoulos HM. Sjogren's syndrome. Annu Rev Pathol. (2014) 9:273-85. doi: 10.1146/annurev-pathol-012513-104728

5. Holdgate N, St Clair EW. Recent advances in primary Sjogren's syndrome. F1000Res. (2016) 5:F1000. doi: 10.12688/f1000research.8352.1

6. Baldini C, Pepe P, Quartuccio L, Priori R, Bartoloni E, Alunno A, et al. Primary Sjogren's syndrome as a multi-organ disease: impact of the serological profile on the clinical presentation of the disease in a large cohort of Italian patients. Rheumatology. (2014) 53:83944. doi: 10.1093/rheumatology/ket427

7. Vakaloglou KM, Mavragani CP. Activation of the type I interferon pathway in primary Sjogren's syndrome: an update. Curr Opin Rheumatol. (2011) 23:459-64. doi: 10.1097/BOR.0b013e328349fd30

8. Rowe D, Griffiths M, Stewart J, Novick D, Beverley PC, Isenberg DA. HLA class I and II, interferon, interleukin 2, and the interleukin 2 receptor expression on labial biopsy specimens from patients with Sjogren's syndrome. Ann Rheum Dis. (1987) 46:580-6. doi: 10.1136/ard.46.8.580

9. Wei W, Ahmad SS, Chi S, Xie Y, Kamal MA, Li J. From molecular mechanism to the etiology of sjogren syndrome. Curr Pharm Des. (2018) 24:417785. doi: 10.2174/1381612824666181016154033

10. Nocturne G, Mariette X. B cells in the pathogenesis of primary Sjögren syndrome. Nat Rev Rheumatol. (2018) 14:13345. doi: 10.1038/nrrheum.2018.1

11. Lessard C, Li H, Adrianto I, Ice J, Rasmussen A, Grundahl K, et al. Variants at multiple loci implicated in both innate and adaptive immune responses are associated with sjögren's syndrome. Nat Genet. (2013) 45:128492. doi: 10.1038/ng.2792

12. Vandenberg O, Kozlakidis Z, Schrenzel J, Struelens M, Breuer J. Control of infectious diseases in the era of European clinical microbiology laboratory consolidation: new challenges and opportunities for the patient and for public health surveillance. Front Med. (2018) 5:15. doi: 10.3389/fmed.2018.00015 more representative mouse models will provide a better research tool for exploration of the nature of SS.

\section{AUTHOR CONTRIBUTIONS}

All authors listed have made a substantial, direct and intellectual contribution to the work, and approved it for publication.

\section{FUNDING}

This work was supported by the National Natural Science Foundation of China (Grant No. 81571593), the start-up packages from the Institute of Psychiatry and Neurology, Xinxiang Medical University, and the Deutsche Forschungsgemeinschaft via Research Training Group GRK1727 Modulation of Autoimmunity and Bundesministerium für Bildung und Forschung (BMBF) via the German Center for Lung Research (DZL).
13. Park Y, Gauna AE, Cha S. Mouse models of primary Sjogren's syndrome. Curr Pharm Des. (2015) 21:235064. doi: 10.2174/1381612821666150316120024

14. Yu X, Huang Q, Petersen F. History and milestones of mouse models of autoimmune diseases. Curr Pharm Des. (2015) 21:2308-19. doi: 10.2174/13816128216661503161 15412

15. Yu X, Petersen F. A methodological review of induced animal models of autoimmune diseases. Autoimmun Rev. (2018) 17:473-9. doi: 10.1016/j.autrev.2018.03.001

16. Petersen F, Yue X, Riemekasten G, Yu X. Dysregulated homeostasis of target tissues or autoantigens - a novel principle in autoimmunity. Autoimmun Rev. (2017) 16:602-11. doi: 10.1016/j.autrev.2017.04.006

17. Donate A, Voigt A, Nguyen CQ. The value of animal models to study immunopathology of primary human Sjogren's syndrome symptoms. Expert Rev Clin Immunol. (2014) 10:469-81. doi: 10.1586/1744666X.2014.883920

18. Lee B, Gauna A, Pauley K, Park Y, Cha S. Animal models in autoimmune diseases: lessons learned from mouse models for Sjögren's syndrome. Clin Rev Allergy Immunol. (2012) 42:35-44. doi: 10.1007/s12016-011-8288-5

19. Robinson C, Yamamoto H, Peck A, Humphreys-Beher M. Genetically programmed development of salivary gland abnormalities in the NOD (nonobese diabetic)-scid mouse in the absence of detectable lymphocytic infiltration: a potential trigger for sialoadenitis of NOD mice. Clin Immunol Immunopathol. (1996). 79:50-9. doi: 10.1006/clin.1996.0050

20. Das B, Cash MN, Robinson B, Kuhns CS, Latchney LR, Fallon MA, et al. The sld genetic defect: two intronic CA repeats promote insertion of the subsequent intron and mRNA decay. J Biol Chem. (2013) 288:1474255. doi: 10.1074/jbc.M113.468645

21. Hayashi Y, Kojima A, Hata M, Hirokawa K. A new mutation involving the sublingual gland in NFS/N mice. Partially arrested mucous cell differentiation. Am J Pathol. (1988) 132:187-91.

22. Saegusa J, Kubota H. Sialadenitis in IQI/Jic mice: a new animal model of Sjogren's syndrome. J Vet Med Sci. (1997) 59:897-903.

23. Asano M, Toda M, Sakaguchi N, Sakaguchi S. Autoimmune disease as a consequence of developmental abnormality of a T cell subpopulation. J Exp Med. (1996) 184:387-96. doi: 10.1084/jem.184.2.387

24. Konno A, Takada K, Saegusa J, Takiguchi M. Presence of B7$2+$ dendritic cells and expression of Th1 cytokines in the early development of sialodacryoadenitis in the IqI/Jic mouse model of primary Sjorgren's syndrome. Autoimmunity. (2003) 36:247-54. doi: 10.1080/0891693031000141077

25. Fisher CR, Graves KH, Parlow AF, Simpson ER. Characterization of mice deficient in aromatase (ArKO) because of targeted 
disruption of the cyp19 gene. Proc Natl Acad Sci USA. (1998) 95:6965-70. doi: 10.1073/pnas.95.12.6965

26. Hayakawa I, Tedder TF, Zhuang Y. B-lymphocyte depletion ameliorates Sjogren's syndrome in Id3 knockout mice. Immunology. (2007) 122:739. doi: $10.1111 / j .1365-2567.2007 .02614 . x$

27. Lawler AJ. The functions of thrombospondin-1 and-2. Curr Opin Cell Biol. (2000). 12:634-40. doi: 10.1016/S0955-0674(00)00143-5

28. Qian Y, Qin J, Cui G, Naramura M, Snow EC, Ware CF, et al. Act1, a negative regulator in CD40- and BAFF-mediated B cell survival. Immunity. (2004) 21:575-87. doi: 10.1016/j.immuni.2004.09.001

29. Ushioda R, Hoseki J, Nagata K. Glycosylation-independent ERAD pathway serves as a backup system under ER stress. Mol Biol Cell. (2013) 24:315563. doi: 10.1091/mbc.e13-03-0138

30. Apostolou E, Moustardas P, Iwawaki T, Tzioufas AG, Spyrou G. Ablation of the chaperone protein ERdj5 results in a Sjogren's syndrome-like phenotype in mice, consistent with an upregulated unfolded protein response in human patients. Front Immunol. (2019) 10:506. doi: 10.3389/fimmu.2019.00506

31. Khare SD, Sarosi I, Xia XZ, McCabe S, Miner K, Solovyev I, et al. Severe B cell hyperplasia and autoimmune disease in TALL-1 transgenic mice. Proc Natl Acad Sci USA. (2000) 97:3370-5. doi: 10.1073/pnas.97.7.3370

32. Green JE, Hinrichs SH, Vogel J, Jay G. Exocrinopathy resembling Sjogren's syndrome in HTLV-1 tax transgenic mice. Nature. (1989) 341:724. doi: $10.1038 / 341072 \mathrm{a} 0$

33. Loiseau P, Lepage V, Djelal F, Busson M, Tamouza R, Raffoux C, et al. HLA class I and class II are both associated with the genetic predisposition to primary sjogren syndrome. Hum Immunol. (2001) 62:72531. doi: 10.1016/S0198-8859(01)00253-1

34. Dawson LJ, Stanbury J, Venn N, Hasdimir B, Rogers SN, Smith PM. Antimuscarinic antibodies in primary Sjogren's syndrome reversibly inhibit the mechanism of fluid secretion by human submandibular salivary acinar cells. Arthritis Rheum. (2006) 54:1165-73. doi: 10.1002/art.21764

35. Nayar S, Campos J, Smith C, Iannizzotto V, Gardner D, Colafrancesco S, et al. Phosphatidylinositol 3-kinase delta pathway: a novel therapeutic target for Sjögren's syndrome. Ann Rheum Dis. (2019) 78:249-60. doi: 10.1136/annrheumdis-2017-212619

36. Jin L, Yu D, Li X, Yu N, Wang Y. CD4+CXCR5+ follicular helper T cells in salivary gland promote B cells maturation in patients with primary Sjogren's syndrome. Int J Clin Exp Pathol. (2014) 7:1988-96.

37. Ishimaru N, Arakaki R, Watanabe M, Kobayashi M, Miyazaki K, Hayashi Y. Development of autoimmune exocrinopathy resembling Sjogren's syndrome in estrogen-deficient mice of healthy background. Am J Pathol. (2003) 163:1481-90. doi: 10.1016/S0002-9440(10)63505-5

38. Xanthou G, Polihronis M, Tzioufas A, Paikos S, Sideras P, Moutsopoulos H. "Lymphoid" chemokine messenger RNA expression by epithelial cells in the chronic inflammatory lesion of the salivary glands of Sjögren's syndrome patients: possible participation in lymphoid structure formation. Arthr Rheum. (2001). 44:40818. doi: 10.1002/1529-0131(200102)44:2<408::AID-ANR60>3.0.CO;2-0

39. Harton JA Ting JP. Class II transactivator: mastering the art of major histocompatibility complex expression. Mol Cell Biol. (2000) 20:618594. doi: $10.1128 / .20 .17 .6185-6194.2000$

40. Cavanaugh VJ, Deng Y, Birkenbach MP, Slater JS, Campbell AE. Vigorous innate and virus-specific cytotoxic T-lymphocyte responses to murine cytomegalovirus in the submaxillary salivary gland. J Virol. (2003) 77:170317. doi: 10.1128/JVI.77.3.1703-1717.2003

41. Scofield RH, Asfa S, Obeso D, Jonsson R, Kurien BT. Immunization with short peptides from the $60-\mathrm{kDa}$ Ro antigen recapitulates the serological and pathological findings as well as the salivary gland dysfunction of Sjogren's syndrome. J Immunol. (2005) 175:8409-14. doi: 10.4049/jimmunol.175.12.8409

42. Makino S, Kunimoto K, Muraoka Y, Mizushima Y, Katagiri K, Tochino Y. Breeding of a non-obese, diabetic strain of mice. Jikken Dobutsu. (1980) 29:1-13. doi: 10.1538/expanim1978.29.1_1

43. Hu Y, Nakagawa Y, Purushotham KR, Humphreys-Beher MG. Functional changes in salivary glands of autoimmune disease-prone NOD mice. Am J Physiol. (1992) 263:E607-14. doi: 10.1152/ajpendo.1992.263.4.E607

44. Humphreys-Beher MG, Hu Y, Nakagawa Y, Wang PL, Purushotham KR. Utilization of the Non-Obese Diabetic (NOD) mouse as an animal model for the study of secondary Sjogren's syndrome. Adv Exp Med Biol. (1994) 350:631-6. doi: 10.1007/978-1-4615-2417-5_105

45. Winer S, Astsaturov I, Cheung R, Tsui H, Song A, Gaedigk R, et al. Primary sjögren's syndrome and deficiency of ICA69. Lancet. (2002) 360:10639. doi: 10.1016/S0140-6736(02)11144-5

46. Cha S, Nagashima H, Brown V, Peck A, Humphreys-Beher M. Two NOD Idd-associated intervals contribute synergistically to the development of autoimmune exocrinopathy (Sjögren's syndrome) on a healthy murine background. Arthritis Rheum. (2002) 46:1390-8. doi: 10.1002/art.10258

47. Robinson CP, Yamachika S, Bounous DI, Brayer J, Jonsson R, Holmdahl R, et al. A novel NOD-derived murine model of primary Sjogren's syndrome. Arthritis Rheum. (1998) 41:150-6.

48. Wicker LS, Appel MC, Dotta F, Pressey A, Miller BJ, DeLarato NH, et al. Autoimmune syndromes in major histocompatibility complex (MHC) congenic strains of nonobese diabetic (NOD) mice. The NOD MHC is dominant for insulitis and cyclophosphamide-induced diabetes. J Exp Med. (1992) 176:67-77. doi: 10.1084/jem.176.1.67

49. Kiripolsky J, Shen L, Liang Y, Li A, Suresh L, Lian Y, et al. Systemic manifestations of primary Sjögren's syndrome in the NOD.B10Sn-H2/J mouse model. Clin Immunol. (2017) 183:225-32. doi: 10.1016/j.clim.2017.04.009

50. Nguyen C, Singson E, Kim J, Cornelius J, Attia R, Doyle M, et al. Sjögren's syndrome-like disease of C57BL/6.NOD-Aec1 aec2 mice: gender differences in keratoconjunctivitis sicca defined by a cross-over in the chromosome 3 Aec1 locus. Scand J Immunol. (2006) 64:295307. doi: 10.1111/j.1365-3083.2006.01828.x

51. Jin J, Kawai $\mathrm{T}$, Cha $\mathrm{S}, \mathrm{Yu}$ Q. Interleukin-7 enhances the Th1 response to promote the development of sjögren's syndromelike autoimmune exocrinopathy in mice. Arthr Rheum. (2013) 65:2132-42. doi: 10.1002/art.38007

52. Jin J, Shinohara Y, Yu Q. Innate immune signaling induces interleukin7 production from salivary gland cells and accelerates the development of primary Sjögren's syndrome in a mouse model. PLoS ONE. (2013) 8:e77605. doi: 10.1371/journal.pone.0077605

53. Cha S, Brayer J, Gao J, Brown V, Killedar S, Yasunari U, et al. A dual role for interferon-gamma in the pathogenesis of Sjogren's syndromelike autoimmune exocrinopathy in the nonobese diabetic mouse. Scand $J$ Immunol. (2004) 60:552-65. doi: 10.1111/j.0300-9475.2004.01508.x

54. Robinson C, Brayer J, Yamachika S, Esch T, Peck A, Stewart C, et al. Transfer of human serum IgG to nonobese diabetic Igmu null mice reveals a role for autoantibodies in the loss of secretory function of exocrine tissues in Sjögren's syndrome. Proc Natl Acad Sci USA. (1998) 95:753843. doi: $10.1073 /$ pnas. 95.13 .7538

55. Brayer J, Cha S, Nagashima H, Yasunari U, Lindberg A, Diggs S, et al. IL4-dependent effector phase in autoimmune exocrinopathy as defined by the NOD.IL-4-gene knockout mouse model of Sjogren's syndrome. Scand J Immunol. (2001) 54:133-40. doi: 10.1046/j.1365-3083.2001.00958.x

56. Gao J, Killedar S, Cornelius JG, Nguyen C, Cha S, Peck AB. Sjogren's syndrome in the NOD mouse model is an interleukin-4 time-dependent, antibody isotype-specific autoimmune disease. J Autoimmun. (2006) 26:90103. doi: 10.1016/j.jaut.2005.11.004

57. Robinson CP, Cornelius J, Bounous DI, Yamamoto H, Humphreys-Beher MG, Peck AB. Infiltrating lymphocyte populations and cytokine production in the salivary and lacrimal glands of autoimmune NOD mice. Adv Exp Med Biol. (1998) 438:493-7. doi: 10.1007/978-1-4615-5359-5_68

58. Haneji N, Hamano H, Yanagi K, Hayashi Y. A new animal model for primary Sjogren's syndrome in NFS/sld mutant mice. J Immunol. (1994) 153:2769-77.

59. Haneji N, Nakamura T, Takio K, Yanagi K, Higashiyama H, Saito I, et al. Identification of alpha-fodrin as a candidate autoantigen in primary Sjogren's syndrome. Science. (1997) 276:604-7. doi: 10.1126/science.276.5312.604

60. Ishimaru N, Saegusa K, Yanagi K, Haneji N, Saito I, Hayashi Y. Estrogen deficiency accelerates autoimmune exocrinopathy in murine Sjogren's syndrome through fas-mediated apoptosis. Am J Pathol. (1999) 155:17381. doi: 10.1016/S0002-9440(10)65111-5

61. Ishimaru N, Yoneda T, Saegusa K, Yanagi K, Haneji N, Moriyama K, et al. Severe destructive autoimmune lesions with aging in murine Sjogren's syndrome through fas-mediated apoptosis. Am J Pathol. (2000) 156:155764. doi: 10.1016/S0002-9440(10)65027-4 
62. Saegusa K, Ishimaru N, Yanagi K, Haneji N, Nishino M, Azuma $\mathrm{M}$, et al. Treatment with anti-CD86 costimulatory molecule prevents the autoimmune lesions in murine Sjogren's syndrome (SS) through up-regulated Th2 response. Clin Exp Immunol. (2000) 119:354-60. doi: 10.1046/j.1365-2249.2000.01121.x

63. Ishimaru N, Takagi A, Kohashi M, Yamada A, Arakaki R, Kanno J, et al. Neonatal exposure to low-dose 2,3,7,8-tetrachlorodibenzo-p-dioxin causes autoimmunity due to the disruption of T cell tolerance. J Immunol. (2009) 182:6576-86. doi: 10.4049/jimmunol.0802289

64. Tsubota K, Fujita H, Tadano K, Takeuchi T, Murakami T, Saito I, et al. Improvement of lacrimal function by topical application of CyA in murine models of Sjögren's syndrome. Invest Ophthalmol Visual Sci. (2001) 42:10110 .

65. Azuma M, Ashida Y, Tamatani T, Motegi K, Takamaru N, Ishimaru N, et al. Cepharanthin, a biscoclaurine alkaloid, prevents destruction of acinar tissues in murine Sjögren's syndrome. J Rheumatol. (2006) 33:912-20.

66. Yamada A, Ushio A, Arakaki R, Tsunematsu T, Kudo Y, Hayashi Y, et al. Impaired expansion of regulatory $\mathrm{T}$ cells in a neonatal thymectomyinduced autoimmune mouse model. Am J Pathol. (2015) 185:288697. doi: 10.1016/j.ajpath.2015.07.007

67. Saegusa J, Yamamoto S, Iwai H, Ueda K. Antinucleolar autoantibody induced in mice by mercuric chloride. Ind Health. (1990) 28:2130. doi: 10.2486 /indhealth. 28.21

68. Takada K, Takiguchi M, Konno A, Inaba M. Autoimmunity against a tissue kallikrein in IQI/Jic Mice: a model for Sjogren's syndrome. J Biol Chem. (2005) 280:3982-8. doi: 10.1074/jbc.M410157200

69. Takada K, Takiguchi M, Inaba M. Different effects on the inflammatory lesions in the lacrimal and salivary glands after neonatal thymectomy in IQI/Jic mice, a model for Sjogren's syndrome. J Vet Med Sci. (2005) 67:9557. doi: 10.1292/jvms.67.955

70. Miyawaki S, Nakamura Y, Suzuka H, Koba M, Yasumizu R, Ikehara S, et al. A new mutation, aly, that induces a generalized lack of lymph nodes accompanied by immunodeficiency in mice. Eur J Immunol. (1994) 24:42934. doi: 10.1002/eji.1830240224

71. Yamada T, Mitani T, Yorita K, Uchida D, Matsushima A, Iwamasa K, et al. Abnormal immune function of hemopoietic cells from alymphoplasia (aly) mice, a natural strain with mutant NF-kappa B-inducing kinase. J Immunol. (2000) 165:804-12. doi: 10.4049/jimmunol.165.2.804

72. Tsubata R, Tsubata T, Hiai H, Shinkura R, Matsumura R, Sumida T, et al. Autoimmune disease of exocrine organs in immunodeficient alymphoplasia mice: a spontaneous model for Sjogren's syndrome. Eur J Immunol. (1996) 26:2742-8. doi: 10.1002/eji.1830261129

73. Wang H, Yi S, Li J, Terayama H, Naito M, Hirai S, et al. Effects of splenectomy on spontaneously chronic pancreatitis in aly/aly mice. Clin Dev Immunol. (2010) 2010:614890. doi: 10.1155/2010/614890

74. Kobayashi S, Ueda A, Ueda M, Nawa K. Pathology of spontaneous dermatitis in CBy.ALY-aly mice. Exp Anim. (2008) 57:159-163. doi: 10.1538/expanim.57.159

75. Seo Y, Fukushima H, Maruyama T, Kuroishi K, Osawa K, Nagano K, et al. Accumulation of p100, a precursor of NF-кB2, enhances osteoblastic differentiation in vitro and bone formation in vivo in aly/aly mice. $\mathrm{Mol}$ Endocrinol. (2012) 26:414-22. doi: 10.1210/me.2011-1241

76. Nelson DR, Kamataki T, Waxman DJ, Guengerich FP, Estabrook RW, Feyereisen R, et al. The P450 superfamily: update on new sequences, gene mapping, accession numbers, early trivial names of enzymes, and nomenclature. DNA Cell Biol. (1993) 12:1-51. doi: 10.1089/dna.1993.12.1

77. Shim GJ, Warner M, Kim HJ, andersson S, Liu L, Ekman J, et al. Aromatasedeficient mice spontaneously develop a lymphoproliferative autoimmune disease resembling Sjogren's syndrome. Proc Natl Acad Sci USA. (2004) 101:12628-33. doi: 10.1073/pnas.0405099101

78. Iwasa A, Arakaki R, Honma N, Ushio A, Yamada A, Kondo $\mathrm{T}$, et al. Aromatase controls Sjogren syndrome-like lesions through monocyte chemotactic protein-1 in target organ and adipose tissue-associated macrophages. Am J Pathol. (2015) 185:151-61. doi: 10.1016/j.ajpath.2014.09.006

79. Pavlopoulos E, Jones S, Kosmidis S, Close M, Kim C, Kovalerchik $\mathrm{O}$, et al. Molecular mechanism for age-related memory loss: the histone-binding protein RbAp48. Sci Transl Med. (2013) 5:200ra115. doi: 10.1126/scitranslmed.3006373

80. Ishimaru N, Arakaki R, Omotehara F, Yamada K, Mishima K, Saito I, et al. Novel role for RbAp48 in tissue-specific, estrogen deficiencydependent apoptosis in the exocrine glands. Mol Cell Biol. (2006) 26:292435. doi: 10.1128/MCB.26.8.2924-2935.2006

81. Ishimaru N, Arakaki R, Yoshida S, Yamada A, Noji S, Hayashi Y. Expression of the retinoblastoma protein RbAp48 in exocrine glands leads to Sjogren's syndrome-like autoimmune exocrinopathy. J Exp Med. (2008) 205:291527. doi: 10.1084/jem.20080174

82. Bain G, Cravatt CB, Loomans C, Alberola-Ila J, Hedrick SM, Murre C. Regulation of the helix-loop-helix proteins, E2A and Id3, by the Ras-ERK MAPK cascade. Nat Immunol. (2001) 2:165-71. doi: 10.1038/84273

83. Pan L, Sato S, Frederick J, Sun X, Zhuang Y. Impaired immune responses and B-cell proliferation in mice lacking the Id3 gene. Mol Cell Biol. (1999) 19:5969-80. doi: 10.1128/MCB.19.9.5969

84. Rivera RR, Johns CP, Quan J, Johnson RS, Murre C. Thymocyte selection is regulated by the helix-loop-helix inhibitor protein, Id3. Immunity. (2000) 12:17-26. doi: 10.1016/S1074-7613(00)80155-7

85. Li H, Dai M, Zhuang Y. A $\mathrm{T}$ cell intrinsic role of $\mathrm{Id} 3$ in a mouse model for primary Sjogren's syndrome. Immunity. (2004) 21:55160. doi: 10.1016/j.immuni.2004.08.013

86. Sellam J, Miceli-Richard C, Gottenberg J, Proust A, Ittah M, Lavie F, et al. Is Inhibitor of differentiation 3 involved in human primary sjögren's syndrome? Rheumatology. (2008) 47:437-41. doi: 10.1093/rheumatology/ken013

87. Deane JA, Trifilo MJ, Yballe CM, Choi S, Lane TE, Fruman DA. Enhanced T cell proliferation in mice lacking the p85beta subunit of phosphoinositide 3kinase. J Immunol. (2004) 172:6615-25. doi: 10.4049/jimmunol.172.11.6615

88. Fruman DA Bismuth G. Fine tuning the immune response with PI3K. Immunol Rev. (2009) 228:253-72. doi: 10.1111/j.1600-065X.2008.00750.x

89. Oak JS, Deane JA, Kharas MG, Luo J, Lane TE, Cantley LC, et al. Sjogren's syndrome-like disease in mice with $\mathrm{T}$ cells lacking class $1 \mathrm{~A}$ phosphoinositide-3-kinase. Proc Natl Acad Sci USA. (2006) 103:1688216887. doi: 10.1073/pnas.0607984103

90. Ribeiro S, Poczatek M, Schultz-Cherry S, Villain M, and Murphy-Ullrich J. The activation sequence of thrombospondin-1 interacts with the latencyassociated peptide to regulate activation of latent transforming growth factor-beta. J Biol Chem. (1999) 274:13586-93. doi: 10.1074/jbc.274.19.13586

91. Crawford S, Stellmach V, Murphy-Ullrich J, Ribeiro S, Lawler J, Hynes R, et al. Thrombospondin-1 is a major activator of TGF-betal in vivo. Cell. (1998) 93:1159-70. doi: 10.1016/S0092-8674(00)81460-9

92. Turpie B, Yoshimura T, Gulati A, Rios JD, Dartt DA, Masli S. Sjogren's syndrome-like ocular surface disease in thrombospondin-1 deficient mice. Am J Pathol. (2009) 175:1136-47. doi: 10.2353/ajpath.2009.081058

93. Soriano-Romani L, Contreras-Ruiz L, Lopez-Garcia A, Diebold Y, Masli S. Topical application of TGF-beta-activating peptide, KRFK, prevents inflammatory manifestations in the TSP-1-deficient mouse model of chronic ocular inflammation. Int J Mol Sci. (2018) 20:9. doi: 10.3390/ijms20010009

94. Boisson B, Wang C, Pedergnana V, Wu L, Cypowyj S, Rybojad M, et al. An ACT1 mutation selectively abolishes interleukin-17 responses in humans with chronic mucocutaneous candidiasis. Immunity. (2013) 39:67686. doi: 10.1016/j.immuni.2013.09.002

95. Qian Y, Giltiay N, Xiao J, Wang Y, Tian J, Han S, et al. Deficiency of Act1, a critical modulator of B cell function, leads to development of Sjogren's syndrome. Eur J Immunol. (2008) 38:2219-28. doi: 10.1002/eji.200738113

96. Johnson AC, Davison LM, Giltiay NV, Vareechon C, Li X, Jorgensen TN. Lack of $\mathrm{T}$ cells in Act1-deficient mice results in elevated IgM-specific autoantibodies but reduced lupus-like disease. Eur J Immunol. (2012) 42:1695-705. doi: 10.1002/eji.201142238

97. Cunnea P, Miranda V, A, Bertoli G, Simmen T, Damdimopoulos A, et al. ERdj5, an endoplasmic reticulum (ER)-resident protein containing DnaJ and thioredoxin domains, is expressed in secretory cells or following ER stress. J Biol Chem. (2003) 278:1059-66. doi: 10.1074/jbc.M206995200

98. Ushioda R, Miyamoto A, Inoue M, Watanabe S, Okumura M, Maegawa K, et al. Redox-assisted regulation of $\mathrm{Ca} 2+$ homeostasis in the endoplasmic reticulum by disulfide reductase ERdj5. Proc Natl Acad Sci USA. (2016) 113:E6055-63. doi: 10.1073/pnas.1605818113 
99. Oka O, Pringle M, Schopp I, Braakman I, Bulleid N. ERdj5 is the ER reductase that catalyzes the removal of non-native disulfides and correct folding of the LDL receptor. Mol Cell. (2013) 50:793804. doi: 10.1016/j.molcel.2013.05.014

100. Thomas C Spyrou G. ERdj5 sensitizes neuroblastoma cells to endoplasmic reticulum stress-induced apoptosis. J Biol Chem. (2009) 284:628290. doi: 10.1074/jbc.M806189200

101. Hosoda A, Tokuda M, Akai R, Kohno K, Iwawaki T. Positive contribution of ERdj5/JPDI to endoplasmic reticulum protein quality control in the salivary gland. Biochem J. (2009) 425:117-25. doi: 10.1042/BJ20091269

102. Mackay F, Schneider P. Cracking the BAFF code. Nat Rev Immunol. (2009) 9:491-2. doi: 10.1038/nri2572

103. Melchers F. Actions of BAFF in B cell maturation and its effects on the development of autoimmune disease. Ann Rheum Dis. (2003) 62(Suppl 2):25-7. doi: 10.1136/ard.62.suppl_2.ii25

104. Groom J, Kalled SL, Cutler AH, Olson C, Woodcock SA, Schneider $\mathrm{P}$, et al. Association of BAFF/BLyS overexpression and altered B cell differentiation with Sjogren's syndrome. J Clin Invest. (2002) 109:5968. doi: 10.1172/JCI0214121

105. Fletcher CA, Sutherland AP, Groom JR, Batten ML, Ng LG, Gommerman J, et al. Development of nephritis but not sialadenitis in autoimmune-prone BAFF transgenic mice lacking marginal zone B cells. Eur J Immunol. (2006) 36:2504-14. doi: 10.1002/eji.200636270

106. Sipsas NV, Gamaletsou MN, Moutsopoulos HM. Is Sjogren's syndrome a retroviral disease? Arthritis Res Ther. (2011) 13:212. doi: 10.1186/ar3262

107. Hinrichs S, Nerenberg M, Reynolds R, Khoury G, Jay G. A transgenic mouse model for human neurofibromatosis. Science. (1987) 237:13403. doi: $10.1126 /$ science. 2888191

108. Yamazaki S, Muta T, Takeshige K. A novel IkappaB protein, IkappaB-zeta, induced by proinflammatory stimuli, negatively regulates nuclear factor-kappaB in the nuclei. J Biol Chem. (2001) 276:27657-62. doi: 10.1074/jbc.M103426200

109. Okuma A, Hoshino K, Ohba T, Fukushi S, Aiba S, Akira S, et al. Enhanced apoptosis by disruption of the STAT3-IkappaB-zeta signaling pathway in epithelial cells induces Sjogren's syndrome-like autoimmune disease. Immunity. (2013) 38:450-60. doi: 10.1016/j.immuni.2012.11.016

110. Xiao $\mathrm{X}, \mathrm{He} \mathrm{H}$, Lin $\mathrm{Z}$, Luo $\mathrm{P}$, Zhou $\mathrm{T}$, Zhou $\mathrm{Y}$, et al. Therapeutic effects of epidermal growth factor on benzalkonium chloride-induced dry eye in a mouse model. Invest Ophthalmol Visual Sci. (2012) 53:1917. doi: 10.1167/iovs.11-8553

111. White SC Casarett GW. Induction of experimental autoallergic sialadenitis. J Immunol. (1974) 112:178-85.

112. Takeda Y Ishikawa G. Experimental autoallergic sialadenitis in mice. Histopathological and ultrastructural studies. Virchows Arch A Pathol Anat Histopathol. (1983) 400:143-54. doi: 10.1007/BF00585496

113. Wang Y, Yan T, Shen J, Guo H, Xiang X. Preventive effect of ophiopogon japonicus polysaccharides on an autoallergic mouse model for Sjogren's syndrome by regulating the Th1/Th2 cytokine imbalance. J Ethnopharmacol. (2007) 114:246-53. doi: 10.1016/j.jep.2007.08.014

114. Lin X, Rui K, Deng J, Tian J, Wang X, Wang S, et al. Th17 cells play a critical role in the development of experimental Sjogren's syndrome. Ann Rheum Dis. (2015) 74:1302-10. doi: 10.1136/annrheumdis-2013-204584

115. Lin X, Song JX, Shaw PC, Ng TB, Wong RN, Sze SC, et al. An autoimmunized mouse model recapitulates key features in the pathogenesis of Sjogren's syndrome. Int Immunol. (2011) 23:613-24. doi: 10.1093/intimm/ dxr066

116. Pastorekova S, Parkkila S, Pastorek J, Supuran CT. Carbonic anhydrases: current state of the art, therapeutic applications and future prospects. J Enzyme Inhib Med Chem. (2004) 19:199-229. doi: 10.1080/14756360410001689540

117. Majumder S, Takahashi N, Chari ST. Autoimmune pancreatitis. Dig Dis Sci. (2017) 62:1762-9. doi: 10.1007/s10620-017-4541-y

118. Inagaki Y, Jinno-Yoshida Y, Hamasaki Y, Ueki H. A novel autoantibody reactive with carbonic anhydrase in sera from patients with systemic lupus erythematosus and Sjogren's syndrome. J Dermatol Sci. (1991) 2:14754. doi: 10.1016/0923-1811(91)90060-B

119. Caccavo D, Afeltra A, Rigon A, Vadacca M, Zobel BB, Zennaro D, et al. Antibodies to carbonic anhydrase in patients with connective tissue diseases: relationship with lung involvement. Int J Immunopathol Pharmacol. (2008) 21:659-67. doi: 10.1177/039463200802100320

120. Nishimori I, Bratanova T, Toshkov I, Caffrey T, Mogaki M, Shibata Y, et al. Induction of experimental autoimmune sialoadenitis by immunization of PL/J mice with carbonic anhydrase II. J Immunol. (1995) 154:4865-73.

121. Huang R, Yin J, Chen Y, Deng F, Chen J, Gao X, et al. The amino acid variation within the binding pocket 7 and 9 of HLA-DRB1 molecules are associated with primary Sjogren's syndrome. J Autoimmun. (2015) 57:539. doi: 10.1016/j.jaut.2014.11.006

122. Isao N, Eiki M, Kaori M, Takuhiro K, Nobuto O, Saburo O. Diminished cellular immune response to carbonic anhydrase ii in patients with Sjögren's syndrome and idiopathic chronic pancreatitis. J Pancreas. (2004) 5:186-92.

123. Hulme EC, Birdsall NJ, Buckley NJ. Muscarinic receptor subtypes. Annu Rev Pharmacol Toxicol. (1990) 30:633673. doi: 10.1146/annurev.pa.30.040190.003221

124. Kyriakidis NC, Kapsogeorgou EK, Tzioufas AG. A comprehensive review of autoantibodies in primary Sjogren's syndrome: clinical phenotypes and regulatory mechanisms. J Autoimmun. (2014) 51:67-74. doi: 10.1016/j.jaut.2013.11.001

125. Zuo J, Williams AE, Park YJ, Choi K, Chan AL, Reeves WH, et al. Muscarinic type 3 receptor autoantibodies are associated with anti-ssa/ro autoantibodies in Sjogren's syndrome. J Immunol Methods. (2016) 437:2836. doi: 10.1016/j.jim.2016.07.003

126. Iizuka M, Wakamatsu E, Tsuboi H, Nakamura Y, Hayashi T, Matsui M, et al. Pathogenic role of immune response to M3 muscarinic acetylcholine receptor in Sjogren's syndrome-like sialoadenitis. J Autoimmun. (2010) 35:383-9. doi: 10.1016/j.jaut.2010.08.004

127. Tahara M, Tsuboi H, Segawa S, Asashima H, Iizuka-Koga M, Hirota T, et al. RORgammat antagonist suppresses M3 muscarinic acetylcholine receptorinduced Sjogren's syndrome-like sialadenitis. Clin Exp Immunol. (2017) 187:213-24. doi: 10.1111/cei.12868

128. Provost TT. Anti-Ro(SSA) and anti-La(SSB) antibodies in lupus erythematosus and Sjogren's syndrome. Keio J Med. (1991). 40:72-7. doi: 10.2302/kjm.40.72

129. Kurien BT, Dsouza A, Igoe A, Lee YJ, Maier-Moore JS, Gordon T, et al. Immunization with $60 \mathrm{kD}$ Ro peptide produces different stages of preclinical autoimmunity in a Sjogren's syndrome model among multiple strains of inbred mice. Clin Exp Immunol. (2013) 173:67-75. doi: 10.1111/cei.12094

130. Zheng J, Huang Q, Huang R, Deng F, Yue X, Yin J, et al. B cells are indispensable for a novel mouse model of primary Sjogren's syndrome. Front Immunol. (2017) 8:1384. doi: 10.3389/fimmu.2017.01384

131. Deshmukh US, Lewis JE, Gaskin F, Kannapell CC, Waters ST, Lou YH, et al. Immune responses to Ro60 and its peptides in mice. I. The nature of the immunogen and endogenous autoantigen determine the specificities of the induced autoantibodies. J Exp Med. (1999) 189:53140. doi: 10.1084/jem.189.3.531

132. Yin J, Zheng J, Deng F, Zhao W, Chen Y, Huang Q, et al. Gene expression profiling of lacrimal glands identifies the ectopic expression of mhc ii on glandular cells as a presymptomatic feature in a mouse model of primary Sjogren's syndrome. Front Immunol. (2018) 9:2362. doi: 10.3389/fimmu.2018.02362

133. Lagenaur LA, Manning WC, Vieira J, Martens CL, Mocarski ES. Structure and function of the murine cytomegalovirus sggl gene: a determinant of viral growth in salivary gland acinar cells. J Virol. (1994) 68:771727. doi: 10.1128/JVI.68.12.7717-7727.1994

134. Henson D Strano AJ. Mouse cytomegalovirus. Necrosis of infected and morphologically normal submaxillary gland acinar cells during termination of chronic infection. Am J Pathol. (1972) 68:183-202.

135. Fleck M, Kern ER, Zhou T, Lang B, Mountz JD. Murine cytomegalovirus induces a Sjogren's syndrome-like disease in C57Bl/6-lpr/lpr mice. Arthritis Rheum. (1998) 41:2175-84.

136. Ohyama Y, Carroll VA, Deshmukh U, Gaskin F, Brown MG, Fu SM. Severe focal sialadenitis and dacryoadenitis in NZM2328 mice induced by MCMV: a novel model for human Sjogren's syndrome. J Immunol. (2006) 177:73917. doi: 10.4049/jimmunol.177.10.7391

137. Jonsson M, Skarstein K, Jonsson R, Brun J. Serological implications of germinal center-like structures in primary Sjögren's syndrome. J Rheumatol. (2007) 34:2044-9. 
138. Barone F, Bombardieri M, Manzo A, Blades M, Morgan P, Challacombe S, et al. Association of CXCL13 and CCL21 expression with the progressive organization of lymphoid-like structures in Sjögren's syndrome. Arthr Rheum. (2005) 52:1773-84. doi: 10.1002/art.21062

139. Bombardieri M, Barone F, Lucchesi D, Nayar S, van-den-Berg W, Proctor $\mathrm{G}$, et al. Inducible tertiary lymphoid structures, autoimmunity, and exocrine dysfunction in a novel model of salivary gland inflammation in C57BL/6 mice. J Immunol. (2012) 189:3767-76. doi: 10.4049/jimmunol.1201216

140. Amft N, Curnow S, Scheeltoellner D, Devadas A, Oates J, Crocker $\mathrm{J}$, et al. Ectopic expression of the $\mathrm{B}$ cell-attracting chemokine BCA-1 (CXCL13) on endothelial cells and within lymphoid follicles contributes to the establishment of germinal center-like structures in Sjogren's syndrome. Arthr Rheum. (2001) 44:263341. doi: 10.1002/1529-0131(200111)44:11<2633::AID-ART443>3.0.CO;2-9

141. Nayar S, Campos J, Smith C, Iannizzotto V, Gardner D, Mourcin F, et al. Immunofibroblasts are pivotal drivers of tertiary lymphoid structure formation and local pathology. Proc Natl Acad Sci USA. (2019) 116:134907. doi: 10.1073/pnas.1905301116

142. Szabo K, Papp G, Barath S, Gyimesi E, Szanto A, Zeher M. Follicular helper $\mathrm{T}$ cells may play an important role in the severity of primary Sjogren's syndrome. Clin Immunol. (2013) 147:95-104. doi: 10.1016/j.clim.2013.02.024

143. Kramer JM. Early events in Sjogren's Syndrome pathogenesis: the importance of innate immunity in disease initiation. Cytokine. (2014). 67:92101. doi: 10.1016/j.cyto.2014.02.009

144. Hayashi T. Dysfunction of lacrimal and salivary glands in Sjogren's syndrome: nonimmunologic injury in preinflammatory phase and mouse model. J Biomed Biotechnol. (2011) 2011:407031. doi: 10.1155/2011/ 407031

145. Kong L, Robinson CP, Peck AB, Vela-Roch N, Sakata KM, Dang H, et al. Inappropriate apoptosis of salivary and lacrimal gland epithelium of immunodeficient NOD-scid mice. Clin Exp Rheumatol. (1998) $16: 675-81$.

146. Nguyen CQ, Sharma A, Lee BH, She JX, McIndoe RA, Peck AB. Differential gene expression in the salivary gland during development and onset of xerostomia in Sjogren's syndrome-like disease of the C57BL/6.NODAec1Aec2 mouse. Arthritis Res Ther. (2009) 11:R56. doi: 10.1186/ar2676

147. Killedar S, Eckenrode S, McIndoe R, She J, Nguyen C, Peck A, et al. Early pathogenic events associated with Sjogren's syndrome (SjS)-like disease of the NOD mouse using microarray analysis. Lab Invest. (2006) 86:124360. doi: 10.1038/labinvest.3700487

148. Hobart M, Ramassar V, Goes N, Urmson J, Halloran PF. IFN regulatory factor-1 plays a central role in the regulation of the expression of class I and II MHC genes in vivo. J Immunol. (1997) 158:4260-9.

149. Steimle V, Siegrist CA, Mottet A, Lisowska-Grospierre B, Mach B. Regulation of MHC class II expression by interferon-gamma mediated by the transactivator gene CIITA. Science. (1994) 265:106-9. doi: 10.1126/science.8016643

150. Delaleu N, Nguyen CQ, Peck AB, Jonsson R. Sjögren's syndrome: studying the disease in mice. Arthr Res Ther. (2011) 13:217. doi: 10.1186/ar3313

151. Mestas J, Hughes CCW. Of mice and not men: differences between mouse and human immunology. J Immunol. (2004). 172:2731-8. doi: 10.4049/jimmunol.172.5.2731

152. Esmerina T, Jacques MJ, ChangGong L, Hansjuerg A, Cristian T, Stefano $\mathrm{V}$, et al. GAM/ZFp/ZNF512B is central to a gene sensor circuitry involving cell-cycle regulators, TGFß effectors, drosha and microRNAs with opposite oncogenic potentials. Nucleic Acids Res. (2010) 38:767388. doi: 10.1093/nar/gkq637

Conflict of Interest: The authors declare that the research was conducted in the absence of any commercial or financial relationships that could be construed as a potential conflict of interest.

Copyright (c) 2020 Gao, Chen, Zhang, Yu and Zheng. This is an open-access article distributed under the terms of the Creative Commons Attribution License (CC BY). The use, distribution or reproduction in other forums is permitted, provided the original author(s) and the copyright owner(s) are credited and that the original publication in this journal is cited, in accordance with accepted academic practice. No use, distribution or reproduction is permitted which does not comply with these terms. 